\title{
Regression to Mediocrity? Surnames and Social Mobility in England, 1200-2009
}

\author{
Gregory Clark \\ gclark@ucdavis.edu. \\ June 30, 2010
}

\begin{abstract}
This paper reports on a preliminary investigation of surname distributions as a measure long run social mobility. ${ }^{1}$ In England this suggests two surprising claims. First, England, all the way from the heart of the Middle Ages in 1200 to 2009, is a society without persistent social classes, at least among the descendants of the medieval population. It was a world of complete social mobility, with no permanent over-class and under-class, a world of complete equal opportunity. However, for some recent immigrant groups it may no longer be true. Instead of moving from a world of immobility and class rigidity in medieval England to a world of equal opportunity, we may have moved in the opposite direction. Other modern societies such as the US and Brazil also show sign of persistent social classes. There was, however, a gain from being in the upper class before 1800 in any generation in the form of leaving more copies of your DNA permanently in later populations.
\end{abstract}

\section{Introduction}

In 1886 Francis Galton - the famous anthropologist, eugenicist, geographer, inventor, meteorologist, polymath, statistician, tropical explorer, and second cousin of Darwin - published a fabulous discovery which he labeled "regression towards mediocrity."2 Galton's paper showed the tendency of both tall and short parents to

\footnotetext{
${ }^{1}$ The concern here is social mobility over many generations. There have been some recent papers that use the information content of names similarly to measure the rate of social mobility between generations. See, for example, Güell, Maia, José V. Rodríguez Mora, and Telmer, Chris, 2007.

2 Galton, 1886. Galton had announced initial observation on regression to the mean with sweet pea sizes in 1877, but in the 1886 paper he announced the finding as a general law applying to all hereditary traits.
} 
have children whose heights tended towards the mean of the society. This might seem small potatoes, but Galton had uncovered a general process - regression to the mean - with potentially profound social implications, since it applies to all personal characteristics including education, IQ, income and wealth. It is a process that has led free-market economists such as Gary Becker to proclaim

Almost all earnings advantages and disadvantages of ancestors are wiped out in three generations. Poverty would not seem to be a "culture" that persists for several generations ${ }^{3}$

If Becker is correct Galton's discovering shows that there cannot now be social classes - meaning persistent groups of privileged and poor - in meritocratic societies such as England and the USA where regression to the mean is strong. Within a few generations, a very few generations, there must be a complete churning of the society: the descendants of the poorest and the richest will be equally represented. Whatever its appearance in the small, we live in a profoundly egalitarian society once we move to the scale of generations. Class is the illusion of the moment. ${ }^{4}$

Yet even now we live in a world where the average person has a strong belief in the reality and persistence of class. We all know there is some social mobility. But we assume still that the children at Choate, Hotchkiss and Groton, or at Eton, Harrow and Rugby, are mainly drawn from some timeless elite. When we see pictures of inner city deprivation we do not think these are the ultimate offspring of middle class households like our own. Rather we assume them the latest generation of a permanent and persistent underclass, which thankfully our own descendants will never inhabit.

English historians, similarly, while debating the degree to which the preindustrial English upper classes were an "open" elite, still assume that

The English elite of the seventeenth and eighteenth centuries was full of old families....Great families, often growing more prosperous and prestigious over time but important even in the fourteenth and fifteenth centuries and frequently retaining their

3 Becker and Tomes, 1986, S32. Gary Solon and others have since established that regression to the mean is less strong than Becker and Tomes believed. But that just means the quote would need to be amended to "wiped out in five generations." See Solon, 1999, Bowles and Gintis, 2002.

4 The dystopic vision of Herrnstein and Murray, 1996, of a modern society divided into classes based on genetically transmitted IQ has also been criticized as incompatible with the strong observed regression to the mean of all human traits. 
original patrimony....Many of their names are familiar to any student of English

history: Berkeley, Cavendish, Courtenay, Herbert, Howard, Lowther, Manners,

Pelham, Stanley, and Talbot. (Wasson, 1998, 35).

Elite society was not closed to new entrants, but it had long persisting members. Our impression of long run social rigidity is reinforced by the accounts of families such as that of the Earls of Derby. The current Earl of Derby, Edward Richard William Stanley, 19th Earl, can trace his family back to Ligulf of Aldithley, an English landowner who appears in the Domesday Book. His ancestors include Thomas Stanley, the 1st Earl of Derby, 1435-1504, who crowned Henry VII after Battle of Bosworth Field and Edward Smith-Stanley, 14th Earl of Derby, 1799-1869, Prime Minister of the United Kingdon, 1852, 1858-9, and 1866-8. A family that can survive 29 generations at the upper reaches of English society implies a strong social rigidity, and persistent social classes.

Social mobility is, of course, a matter of keen interest to all upper class parents in any society. While we celebrate mobility in the abstract, we struggle ferociously in the concrete to frustrate it. At the personal level we desperately hope that there is a ruling class, and that our children and grandchildren can remain within its warm embrace. We do not see the future of our offspring as an eventual decline back to mediocrity.

The central question this paper addresses is whether this is a grand illusion? Was there ever - even in the dark heart of medieval England - a ruling class? A ruling class, that is, in the sense of a persistent, upper class, strata within the society? Was there, in conjunction, even in the era of lord and serf, ever a persistent underclass? Can most members of the group with the top ten percent of incomes now trace their origins to the ruling class of medieval England? Can most members of the bottom ten percent of the income distribution trace their origins to the landless laborers of the medieval manor? Similarly was there ever a criminal underclass?

What we will learn are two astonishing things. First, pre -modern England, all the way from 1200 to at least 2009, was a society without persistent social classes. It was a world of complete social mobility, with no permanent over-class and underclass. It was, despite all appearances, a world of complete equal opportunity. George Orwell could not be more incorrect when he observed: England is the most class-ridden country under the sun. It is a land of snobbery and privilege (George Orwell, 1941). 
Second, persistent social classes have only emerged in societies like England and the United States in recent years. We congratulate ourselves that we have created a meritocracy with access for all compared to the bad old days. Yet instead of moving from a world of immobility and class rigidity to a world of complete mobility we have moved in the opposite direction. The US, for example, now exhibits persistent upper and under classes and there are indications that the same may be true for modern Britain. Why this has happened is, of course, of considerable interest and concern.

\section{The Mathematics of Mobility}

The evidence on social mobility in the long run is surprisingly limited. The reason for this is that most studies of social mobility have looked only at parents and children. Linking people through three or more generations is difficult, and has been done rarely. ${ }^{5}$

These two-generation studies consistently do find Galton's "regression to the mean." The children of the rich are poorer than their parents, the children of the poor are richer than their parents. It applies to all characteristics that can be measured for parents and children.

Thus if we measure the logarithm of the income or wealth of the parents relative to the average by $y_{0}$, and that of the children by $y_{1}$ then we can estimate empirically the value of the coefficient $b$ in the expression ${ }^{6}$

$$
y_{1}=b y_{0}+u_{0}
$$

If $\mathrm{b}$ is 1 , then the best predictor of the children's income is that of their parents and there is no regression to the mean. In this case there would be persistent social classes. In practice modern estimates of $\mathrm{b}$ vary between 0.2 and 0.5 , implying

\footnotetext{
5 Biblarz, Bengtson, and Bucur, 1996, look explicitly at three generations, but consider only the nature of parent-child linkages across different generations.

${ }^{6}$ Since we are measuring the logarithm of income relative to the average, the average value of $y_{0}$ will be 0 .
} 
substantial regression to the mean. ${ }^{7}$ A coefficient of 0.5 implies that if a parent has income double the national average then their children on average would have an income level only 50\% above the national average. Figure 1 shows what regression to the mean looks like in practice, for the case where $\mathrm{b}=0.5 .^{8}$

\section{FIGURE 1 HERE}

Observing the intergenerational regression of income, wealth and status to the mean, some free market advocates such as Gary Becker have argued that with enough time we are in a society of complete social mobility. The argument is by iteration. Assuming for the next generation that

$$
y_{1}=b y_{0}+u_{0} \quad, b<1
$$

then $\quad y_{n}=b^{n} y_{0}+u^{*}{ }_{n}$

As $n$ becomes large,

$$
b^{n} \approx 0, \text { so } y_{n} \approx u_{n}^{*}
$$

where

$$
u_{n}^{*}=b^{n-1} u_{0}+b^{n-2} u_{1}+\ldots \ldots+u_{n} \quad .
$$

The expected log income of descendants after a large number of generations, whatever the initial income $\mathrm{y}_{0}$, is 0 . The regression of expected income to the mean value for the society will occur very quickly if $\mathrm{b}$ has a commonly estimated value such as 0.5 . If the parents, for example, have an income $500 \%$ of the social mean, then for grandchildren it will be 150\%, and for great-grandchildren $122 \%$. Figure 2 shows how rapid the process of regression to the mean will be between generations for values of $\mathrm{b}$ even as high as 0.6.

\section{FIGURE 2 HERE}

\footnotetext{
${ }^{7}$ Solon, 1999.

8 With a stable distribution of wealth or income over time, $\mathrm{b}$ also indicates how much of the variation in income in societies is explicable from inheritance. The share so explained will be $b^{2}$. This means that with $a b$ of 0.5 , only about 0.25 of the variance of incomes in each generation is explained by inheritance.
} 
However, the one generational regression to the mean that is typically observed is compatible with a very different potential implication about long run social mobility. To see this assume that the initial income has two components, so that

$$
y_{0}=z+e_{0}
$$

$z$ is the systematic component of the income, determined by such things as genetics and social class, and $e_{0}$ is the random component. Suppose that $z$ gets faithfully transmitted between generations. ${ }^{9}$ There are upper and lower classes. Then the income of the next generation will be

$$
y_{1}=z+e_{1}
$$

where the average value of $z$, by construction, is 0 . Suppose that society consists of a group of people of such different economic classes $z_{1}, z_{2}, \ldots . z_{n}$. What would the global connection between fathers' and sons' income look like in this case? If we regress $y_{1}$ on $y_{0}$ then the estimated value of $\mathrm{b}$ will be

$$
\widehat{b}=1-\frac{\sigma_{e}^{2}}{\sigma_{z}^{2}+\sigma_{e}^{2}}
$$

Where $\sigma_{e}^{2}$ is the variance of the part of income arising as an idiosyncratic component in each generation, and $\sigma_{z}^{2}$ is the variance of the part of income that is systematic and inheritable. If these variances were equal $\hat{b}$ would be estimated as 0.5 . There will thus be the classic regression to the mean.

Figure 3 shows a simulation of this where there are two social classes, with the first (shown by the squares) having an underlying inherited component of income 3, and the second (the triangles) an inherited component of 5. Around each of these means there are random deviations. But the underlying mean of each group is fixed over time. In this case there are social classes that persist. But if we just take the raw data and estimate the coefficient $b$ in the expression

$$
y_{1}=b y_{0}+u_{0}
$$

9 This will only happen if there is perfect assortative mating, so that everyone marries someone with the same underlying value of $\%$ 
then the estimated value of $\mathrm{b}$ is 0.5 . The dashed line shows the estimated connection. There is the classic regression to the mean.

\section{FIGURE 3 HERE}

However the expected value of $\mathrm{b}$ in estimating the connection

$$
y_{2}=b y_{0}+u_{0}
$$

between grandfather and grandson, will now be just the same as for the connection between father and son. Similarly for a father and any more distant descendant, the regression coefficient will be no greater. After one generation there will be no further regression to the mean. In this case, depending on the initial values of $z$ there will be persistent social classes. As can be seen in figure 2 the two groups can never merge in income with this specification

If we knew that the parents and children in figure 2 belonged to distinct groups then we could figure out by estimating

$$
y_{1}=a_{i}+b y_{0}+u_{0}
$$

for each group, that the groups were in fact regressing to different mean incomes. In the example shown in Figure 3, once we included separate intercepts for each class, the estimated b becomes close to 0 (-0.04 in fact for this example). But there are persistent classes.

Thomas Hertz carried out exactly such an exercise in a recent study of the link between parental and child income in the USA where he grouped people by race white, black and Latino - and by religion. Table 1 shows his estimated regression coefficients, with and without dummies for race, for a sample of 3,568 parental incomes in 1967-71, and the income of adult children in 1994-2000. As can be seen simply knowing the race of someone in the USA has a powerful effect on the ability to predict their income, even once we control for the family income of the parents. It also significantly increases regression to the mean, though this time to the group mean. This holds true even if we control for all other measured attributes of parents 
in 1967-71 such as education, occupation, and household cleanliness. ${ }^{10}$ These results suggest that indeed the modern USA is a society divided by class, where there is no sign of the ultimate regression to the mean and social mobility that Becker expected.

\section{TABLE 1 HERE}

Hertz's study looked just at the identifiable correlates of class: race and religion. There may be within these populations further hidden divisions of class - but divisions that are not marked by such outward signs as race or religion. There may thus be groups persistently at the top, and those persistently at the bottom, of the income distribution, that the simple analysis of regression to the mean cannot capture.

But if we do not know a priori what the social strata are - because, for example, they are distinguished by race or religion - then there will be no way of disentangling the various social classes. Presented with the raw data we would observe just the general regression to the mean of the world of complete long run mobility. So to observe whether there are persistent social classes in any society we need to be able to look at the experience of regression to the mean across multiple generations. This paper explores methods of measuring social mobility across many generations through the use of surnames.

\section{Surnames and Social Mobility: Common Names 1200-1858}

We can track economic and social mobility using surnames because in England, from medieval times onward, children inherited the surname of the father. Surnames thus trace the patrilineal descendants of men of earlier generations. ${ }^{11}$ Adoption in England before the nineteenth century was rare, so surnames also trace the path of the $\mathrm{Y}$ chromosome, and their later frequency can also measure reproductive success.

${ }^{10}$ Hertz, 2005.

${ }^{11}$ Illegitimate children in England bore the mother's surname. But illegitimacy was uncommon in most of English history. 
In looking at surnames I use two types of analysis. The first concerns common surnames - those held by many people - such as Smith, Clark and Jones. These surnames attached to the population in the Middle Ages, starting with the upper classes, and moving down to the general population. ${ }^{12}$ By 1381 surnames were near universal. ${ }^{13}$ Suppose that at the time of establishment surname types were a marker of economic and social status. Then we can use the social and economic distribution of surnames in later periods as a measure of the mobility of people between social classes, stretching back to the heart of the medieval era in England. By counting the share of their bearers in the population we can also measure reproductive success.

Surnames in England had at least six different origins, as shown in table 2. The first are "locative." These are surnames formed from the place - town, village, county - the bearer originated from or had their estate in. In the medieval period they were typically preceded by a French "de", though over time this was mainly dropped. Thus "Roger de Pakenham" would become "Roger Pakenham." The next category is "toponymic." These referred to the location of the person's house or farm within the village or town. ${ }^{14}$ Patronymic names were formed typically from the father's name. A father called William could thus produce son's with surnames William, Williams, Williamson, Wilson, Wilkins, Wilkinson, Wilcocks, Wilcox: the latter were pet names for William. Nicknames were formed from personal characteristics of the person. Occupational names were formed from occupations, and in the medieval period were sometimes preceded by "le" the French "the." Thus "Robert le Smith," "John le Taylor." The occupations which gave rise to these names were typically those where there was only one such person in a village or settlement: thus Smith, Clerk, Shepherd, Cooper, Carter. Very few people were called "laborer" or "farmer" as their surname. Occupational surnames are the names that most directly convey the original social status of the founder of the line. Table 2 also shows the calculated frequency of surname types among taxpayers in 1327-1332.

\footnotetext{
12 The Domesday book of 1086, records surnames, including combinations of Saxon forenames with Norman family names.

${ }^{13}$ Surnames developed because of the limited variety in forenames. Four or five common male and female first names covered the majority of people before 1800. Surnames became essential to identification in England because it was commercial and mobile by the thirteenth century.

${ }^{14}$ In early years they were often preceded by the English "at" or "atte", though this was later dropped or incorporated into the name. Thus "William atte Helle", "Edward atte Grene."
} 
TABLE 2 HERE

In medieval England there is a strong association between surname type and economic status. We get evidence on upper class surnames in the thirteenth century from such sources as the Inquisitions post Mortem. Inquisitions post mortem were inquiries at the death of feudal tenant in chief (direct tenants of the crown), to establish what lands were held, and who should succeed to them. The holders of these properties were typically members of the upper classes of medieval England. What is distinctive about their surnames is that they commonly had the locative form, where the surname itself referred to the place where they had their major residence. Table 3 shows the distribution of surname types for this wealthy group between 1236 and 1299. 1,598 of 2,138 named deceased - some were just referred to as Earl of Warwick and the like - had names of the explicit "de" form. Only 8 had lower class occupation surnames (Archer, 3, Fletcher, 1, Taylor, 4). Patronyms and toponyms were also very rare: 18 and 4 respectively of the 2,138 .

\section{TABLE 3 HERE}

The first source we get of all surnames for England comes from the 1377-81 Poll Tax returns. These taxes, levied to support the wars of King Richard II in France and Scotland, were assessed on the entire adult population (except clerics) regardless of income or status. A still incomplete analysis of the 1381 returns for Suffolk suggests the name type distribution shown in table 4 . The problem here is that more than half of the surnames are of unknown origin (at the moment). But the share of lower class occupational surnames is still 15 percent, radically higher than for the rich of the IPM. The share of locative surnames is less than 10 percent, though this might be increased once the unknown names are added. Thus we can see the clear class distinction in early English surnames between the rich and the average person.

\section{TABLE 4 HERE}

Even though the 1381 tax was fixed at $12 \mathrm{~d}$ per head, and always $12 \mathrm{~d}$ per person is accounted for in the returns, the individual amounts assessed per person in the village often varied from the $12 \mathrm{~d}$. A minority paid significantly more or less: 571 out of 1,470 payers where the assessment was given. It is clear that the actual payments 
were based on wealth. Thus for 1381 we have measures both of the general surname distribution, and also of the association with status.

Of the 60 taxpayers who paid 24d per head or more for their households, only one had an artisan surname (Skynner), and only one a patronym (Gerard). Nine had locative surnames beginning with the "de." In contrast among the rest of the assessed, 12 percent had artisan surnames (including shepherd and carter). This meant that of 221 lower level artisan surnames with assessed tax listed, only 1 was among the richest tax payers. If artisan names were evenly distributed across wealth we would expect 9 such surnames among the wealthy. Similarly of 144 persons with locative surnames, 15 were among the top 60 tax payers (as compared to an expected 6). Thus still in 1381 there was a class distinction in surname types.

The next set of data we get on the distribution of the surnames for the rich comes from the wills probated at the Prerogative Court of Canterbury (PCC) 13841858. Before 1858 wills were dealt with in ecclesiastical courts. But there was a hierarchy of these courts, with more modest estates probated in local courts and more substantial wills dealt with in the major courts at Canterbury and York. Canterbury was the most important of the ecclesiastical courts that probated wills, dealing with relatively wealthy individuals living mainly in the south of England and Wales (the original ecclesiastical province of Canterbury).

More than 1 million of these wills survive, with Table 5 showing the frequency in terms of distribution by century. Normalizing by the number of adult deaths per year gives an impression, in the last column, of the share of the population they covered. By the eighteenth century 4 percent of those dying in England and Wales would leave wills probated in the Canterbury court. Allowing for those dying intestate, and the fact that will makers were more likely male, represented perhaps the top 10 percent of wealth distribution. In earlier years PCC wills represented a much smaller fraction of deaths, so they may represent a smaller share at the top of the wealth distribution. ${ }^{15}$

15 One problem is that Prerogative Court of Canterbury wills include anyone in England dying abroad, which would include numbers of relatively poor sailors and soldiers from the outposts of the British Empire. Where possible mariners dying abroad were excluded from the counts. 


\section{TABLE 5 HERE}

Over time, particularly over the years 1400-1500, the distribution of names in the Prerogative Court of Canterbury wills changed markedly. Names associated with lower class origins were not found in any PCC wills before 1400, but by 1500 they had risen to what was likely close to the shares of these names in the general population. Figure 4 shows this process for names associated with lower status artisans such as smith, tailor, baker, butcher, cook, wright. There was a rapid increase in the share of these names among PCC wills in the fifteenth century, followed by a rough constancy of shares thereafter. Thus it took only about 150-250 years, 4-7 generations, for the descendants of the original modest artisans to be absorbed completely representatively into the wealthier groups in England.

\section{FIGURE 4 HERE}

We can get an even finer slice of the rich from the PCC wills by focusing on those labeled with "gentleman," "sir," "lord" and other such honorifics This came to stabilize at about 16 percent of all those leaving PCC wills by 1550 and later. ${ }^{16}$ These individuals represented the richest of the PCC testators, and thus typically the top $1 \%$ of less of the wealth distribution of England. Figure 4 also shows the fraction of all "gentleman" testators with lower artisan surnames. Again there is convergence of a stable share of such surnames, though the convergence takes much longer and is not complete until after the 1660s. This implies that in the course of 260 years the artisan class of the middle ages moves from the lower end of the income distribution to being fully represented among the richest in the society. There is complete long run mobility.

Though there is complete mobility, how fast was it? The speed of this observed social mobility in the medieval period depends on when inherited surnames amongst the lower classes first widely appeared. If that was by 1200 then it would have taken 350 years for regression to the mean to have worked its magic. If it was 1350 then the process took only 200-250 years to near completion, which is six or seven generations. Judging whether surnames were inherited, or were merely temporary

\footnotetext{
16 Earlier most wills have no indication of the occupation or status of the testator.
} 
by-names, is difficult, however, from the existing tax and court lists of the medieval period. In 1381 occupational surnames still correlated with actual occupations. Vastly more than a chance number of people worked in the occupation that would be implied by their surname. Of 35 carpenters, for example, 7 bore the name "wright." If surnames by then had become completely hereditary, then either they were formed within a very few generations of 1381, or there was strong intergenerational persistence of occupations.

How strong is the regression to the mean compared to that of modern times? What is the implied $b$ in equation (1) above? We can try and estimate that, as is done below, by looking at the connection between the wealth of fathers and sons. That suggests a value for $b$ of $0.6-0.7$ for the years 1750-1900. Suppose that $b$ was 0.7 also in 1400. Later data from wills suggests that the average artisan in England in the 1620s would on average have a wealth that placed them one third the way up the wealth distribution. Figure 5 shows the proportionate representation, relative to their frequency in the general population, of artisan descendants in the top $15 \%$ and top $1 \%$ of the wealth distribution over each generation. ${ }^{17}$ This suggests that it would take about 6 generations for artisans to become close to proportionately represented among the top $15 \%$ of the wealth distribution (meaning having at least $90 \%$ of their numbers compared from the expected share in the population), and 8 generations to achieve such representation in the top $1 \%$ of wealth. Thus the diffusion of artisan surnames into the upper classes is at a pace that is compatible with (as we shall see) a degree of regression towards the mean that would be the same or little higher than that of modern England.

\section{FIGURE 5 HERE}

Another source is available for the diffusion of artisan names into the upper classes, which are the records of the Exchequer and Prerogative courts of the archdiocese of York in the north of England from 1267 to 1501. The Prerogative court of York is the northern equivalent of the PCC. The Exchequer court dealt

\footnotetext{
${ }^{17}$ In this simulation a crucial element is the variance of the shocks to wealth in each
} generation. This is determined through the formula

$$
\operatorname{var}(y)=\frac{\sigma_{u}^{2}}{1-\beta^{2}}
$$

The variance of the log of wealth, $y$, was estimated from the wealth of testators in the $1620 \mathrm{~s}$ and 1630s. 
with people lower down in the social scale - such as clergy without benefices (endowed positions). Thus these court record relate to a more Catholic share of the population than the PCC data of figure 4. Figure 6 shows the percentage of testators in these courts with artisan names. To establish a baseline, the percentage in the Prerogative Court of York with such names is shows for 1825-49. In the north the percentage of people with artisan surnames by the nineteenth century was higher than in the south, at $7 \%$ of the population. Interestingly by 1400-24 the share of testators in these courts with artisan surnames had already risen to that of the general population. Social mobility was rapid.

\section{FIGURE 6 HERE}

The 1381 data suggests that at this date surnames carried significant information about the economic status of the bearers. It is puzzling, however, that the frequency of occupational surnames is greater than in later populations, even populations as early as 1600. Table 6 thus shows the frequency of a group of common artisanal surnames in Suffolk in 1381. In comparison it shows these surname frequencie in three samples of names in the 1850s: the PCC wills, the accused at the Old Bailey criminal court in London, and the population at large. Somehow the share of artisanal names declined over time. ${ }^{18}$ I posit an explanation of this decline below, but since we do not know when this decline occurred, it implies that it is possible that there had not been complete convergence towards the mean by 1600 by those with artisanal surnames.

However, I can check this by using measures of name frequency at the very lowest end of the income/status spectrum for these years, which were the surnames of laborers who also were criminals, typically petty criminals. These are derived from the assize indictments of Essex for the years 1559-1625, which yields 2,153 male surnames for laborers: the majority of the indicted were "laborers". As table 6 reveals, leaving aside the "smiths", the percentage of those with artisan names among this group was only modestly higher than for the PCC will makers: 4.2 percent versus 3.9 percent. Regression to the mean was largely complete by 1600, in

\footnotetext{
18 The large share of the name "smith" among the accused in the Old Bailey records seems to come from the accused giving false names. Also in the criminal records circa 1600 "smith" is surprisingly common.
} 
the sense that those with artisan forbears had diffused almost equally into the top and the bottom rungs of the society.

\section{TABLE 6 HERE}

The upward mobility of the artisan surnames implies equivalent downward mobility of the names associated with the upper classes in the middle ages, and also of their descendants. Since the upper classes were typically named after their main place of residence we do not, however, expect there to be a high frequency of any particular upper class name. They all started out as relatively rare names. We thus have to form a pool of these names and, see what happens to its frequency over time.

With rarer names there is a problem of their mutation over time. Since they are not anchored to a well known form, like "smith", they can and will mutate, especially for names of foreign origin if their original meaning and significance is lost. Thus in forming a 10 percent sample of the upper class names of 1236-1299 from the Inquisitiones Post Mortem I have deliberately favored those names that correspond to places in England since this will tend to anchor the form of the name over time. Names in this sample included Baskerville, Berkeley, Beaumont, Essex, Hilton, Lancaster, Maundeville (Mandeville), Neville, Normanville, Percy, Somerville, Wake.

Table 7 shows the frequency of these surnames in the PCC from 1380 to 1858 compared to the frequency of these names in the general population. The frequency of names in the general population is estimated in 1381 from the Poll Tax. In 15001858 it is estimated from name frequencies in Boyd's marriage index 1538-1840. The surnames of the medieval elite are initially heavily overrepresented in the PCC wills, but relative to their frequency in the general population the overrepresentation declines steadily over time. Interestingly nearly six hundred years after the identification of this group of names with the rich it is still the case that the bearers, 16 generations later, were better represented among the rich than among those accused of crimes. By 1800-58 it is still there, but is only 4\%. Thus the tale of the Stanley's discussed in the introduction turns out to be an exception. The medieval elites are not able to maintain their position among the rich over time. Regression to the mean takes its toll. The Beckerian vision of the profound equality of societies once a long enough time interval is considered is once again vindicated. 


\section{TABLE 7 HERE}

We can also look at the descent of the descendants of the medieval elite into the criminal underclass. Table 8 shows the relative frequencies of the $10 \%$ sample of the surnames of this elite among both the accused at the Old Bailey in London, and among victims named in the Old Bailey Records. Those with elite surnames are always less likely to be accused than to be victims, but the differential is greatest in the earliest period 1600-99. Figure 7 shows these converging name frequency trends for this elite in the tops and bottom of the socio-economic distribution over time.

\section{TABLE 8 HERE}

\section{FIGURE 7 HERE}

Common English surnames thus largely lost any association with social status by 1600. However, the nineteenth century saw substantial migration into England, principally by the Irish. By 1841 there were 289,000 people of Irish birth living in England. Many Irish surnames, particularly those of Gaelic origin, are quite distinct from those of England. Table 9 also shows the share of defendants and victims in the Old Bailey in London in 1830-1859 with such Irish surnames. For comparison the same percentages are shown for English artisan surnames (except for the surname "smith", for the reasons discussed above), as well as for the distinctive surnames of Scottish immigrants. Also shown is the share of PCC wills made by people with these artisan or Irish surnames resident in London or Middlesex in 1850-8. The later date for the wills was adopted because the Irish population would have been relatively young and growing over time. ${ }^{19}$

\section{TABLE 9 HERE}

For native artisan names, the share of will makers, victims and defendants is very similar. The bearers of artisan surnames are spread evenly from top to bottom of the social hierarchy. However, the bearers of Irish surnames are heavily

\footnotetext{
19 The percent of victims and defendants with names of distinctively Scottish origin is included as another control. If the low ratio of victims to accused for the Irish was a consequence of their immigrant population having a skewed age structure then we would expect that other recent immigrant groups such as the Scots would show a similar pattern.
} 
concentrated at the bottom of the social ladder. They are three times as likely to the defendant in a criminal trial, than the victim of a crime. They are also between 5 and 6 times as likely to be a criminal defendant, than to make a will proved in the high status Canterbury Court. Thus we can potentially use such immigrant groups to measure, using common names, the rate of upward mobility in the years 1800 and later. In the 150 years between 1850 and 2009 have the Irish achieved complete upward mobility within English society $?^{20}$

\section{Social Mobility 1858-2009: Rare Surnames}

After 1650 common surnames lose most of their information about economic status. We can, however, use rare surnames to trace long run social and economic mobility. English surnames exhibited from the earliest years astonishing variety. For the 26 million people in the 1881 census there are 429,000 surnames. A large number of very rare names were just transcription errors. But if we take for example, names held by 5-30 people (to exclude transcription errors), we still find 84,000 names, covering nearly $4 \%$ of the population. The most frequent 40 surnames encompassed only $15 \%$ of the population.

We have a good measure of what surnames were rare in England after 1550 from a variety of sources: the national censuses of 1841 and later, and from 15381840 Boyd's marriage index (together with various supplements) which lists 7 million surnames of people married in England.

By 1600 the average wealth levels of all common names was the same in England. Such names convey no information about social status. But through two forces - the fact that many of those with rare names will be related, and the operation of chance - the average wealth levels of those with rare surnames will vary greatly at any time. We can thus divide people post 1600 into constructed economic strata by focusing on those with rare names.

\footnotetext{
20 This test is complicated by continuing Irish immigration into England between 1850 and 2009 , but a large share of the modern stock of people with distinctively Irish surnames in England in 2009 would have ancestors who arrived before 1914.
} 
For 1858-1879 an initial test sample of 284 rare surnames of testators from the Principle Probate Registry was constructed, the core of which was surnames beginning with " $\mathrm{A}$ " or " $\mathrm{B}$ " in 1858-60 held by 30 or fewer people in the 1881 census. Table 10 shows the distribution of these surnames across 1858-79, and also for two later periods 1888-1909, and 1996-2010.

\section{TABLE 10 HERE}

The names in the sample include some that are foreign imports (Abauzit, Agassiz, Angerstein, Bazalgette, Brunel), some unusual spellings of common names (Apletree, Batcheller, Bisshopp, Bucklee), and some just unusual names (Bagnold, Baldack, Beeland, Binford, Blacksmith, Bollock, Briscomb). The distinctive surname "Bazalgette", for example, was imported into England by Jean Louis Bazalgette (1750-1830) from southern France. Jean Louis was a successful high society tailor who married twice and had 14 children. The name "Binford" which occurs only 19 times in the 1881 census was recorded as early as 1561, and likely first occurred in the middle ages (there is a hamlet called Binford in Shropshire).

The probate registry gives also an estimate of the "personalty" of the testator, the value of their assets other than real estate, which is correlated with their wealth. Taking all pairs of testators with the same surname I can thus test whether there was indeed a correlation of wealth between those of the same rare surname. The estimated value of $b$ between individuals with the same rare surnames in this sample is 0.334 with a standard error of $0.059 .^{21}$ There is a statistically significant link between the wealth of people observed in these years with the same rare surname. We can compare this to the estimated value of $b$ for fathers and sons, and for brothers, for the years 1790-1900 for both personalty, and for a wider measure of total wealth. These estimates are shown in table 11. Looking just at personalty the connection estimate $b$ between those with rare surnames is as close as that between fathers and sons, and brothers.

\section{TABLE 11 HERE}

\footnotetext{
${ }^{21}$ This is calculated regressing each pair of wealth observations for a given name, but correcting with clustering for the non-independence of the error term for each same name pairing.
} 
I also constructed samples from the probate registry for the same names in the next generation (1888-1909), and for the 5.5 ${ }^{\text {th }}$ generation 1996-2010 (assuming a 30 year gap between generations). The numbers in these samples are also shown in table 10. What should happen to the estimated value of $b$ as we move to the next generation, and then to 4.5 generations ahead? If there is a class society in modern England then that estimated $b$ will converge to a number greater than 0 . If, however, there is still complete regression to the mean then the estimated $b$ should decline to close to 0 by 1996-2010. Table 12 shows the estimated value of $b$ for people of the same rare surname in and across each of the cohorts 1858-79, 1888-1909, and 19962010. The correlation in wealth between people with the same surname in the initial and the second cohort falls to 0.23 . That correlation by 1996-2010, at the end of 4.5 generations (assuming a 30 year generation gap), falls to 0.04 , and is not significantly different from 0. This fall occurs despite the fact that from 1996 on the entire net value of the estate, and not just the personalty, is given in the probate record which would reduce the error component.

\section{TABLE 12 HERE}

Figure 8 shows these estimated $b$ 's. Can we potentially infer from this data the rate of regression to the mean across each generation in modern England? Potentially yes. Suppose we estimated the $b$ linking fathers and sons. Suppose also that the measured wealth $Y$ is the true wealth $y$ plus some error $e$. The estimated value by $b$ by OLS would be,

$$
\hat{b}=b\left(\frac{\sigma_{y}^{2}}{\sigma_{y}^{2}+\sigma_{e}^{2}}\right)<b
$$

Suppose we then measured the connection in wealth between fathers and grandsons. With complete regression to the mean the expected coefficient would now be $b^{2}$, but with the same size of the error in measured income the OLS estimated coefficient would be

$$
\widehat{b^{2}}=b^{2}\left(\frac{\sigma_{y}^{2}}{\sigma_{y}^{2}+\sigma_{e}^{2}}\right)<b^{2}
$$

${ }^{22}$ For this insight I am grateful to my colleague Colin Cameron. 
However, the ratio of these two estimates would be the desired coefficient, $b$. If the same process of attenuation between generations operates for the rare surname groups, then by analogy (and this is just an unproven intuition at the moment), the true regression to the mean coefficient $b$ between the 1858-79 and 1888-1909 generation would be from table $12,0.69=.232 / .334$. Figure 8 shows in the dotted line what happens when we project forward to 2010 using this rate of attenuation. The implied results for the link between wealth in 1858-79 and 1996-2010 are close to the observed link. Thus the results seem consistent with low but persistent rates of regression to the mean.

Interestingly while there is complete social mobility, there is more sign of geographic persistence. There were 54 English and Welsh counties in 1858. The chance of any two people being drawn from same county (at their 1851 populations) was $4.1 \%$. In fact rare surnames were not drawn at random from counties. They were heavily concentrated in London and Surrey (31\%), and infrequent in the north and in Wales. Given their distribution across counties the chance that any two at random would be drawn from the same county was $9 \%$ in $1858-79$. In practice $40 \%$ of people with the same rare surname lived in the same county then. Over time the percentage of people with the same rare surname living in the same county declined. But if we look at the distribution of rare surnames in 1996-2010 compared to 18581879, we still find that for any surname the chances that earlier it was located in the same county was still 10\%. Looking at the distribution of the names across counties in 1858-79 and 1996-2010, the chance that by random they would be in the same county is only $6 \%$. Thus there is some geographic persistence of rare surnames, even after 140 years. Geographic mobility may indeed be less than social mobility.

TABLE 13 HERE 


\section{Social Mobility, 1600-1858}

Using the same method of employing rare surnames I can also examine economic mobility 1600-1858. A problem in categorizing early surnames is that English spelling was highly irregular before the nineteenth century. The same surname would have many different variants. Johnson in 1601-2 was spelled Johnson, Johnnsone, Johnsone, Johnsonne, Jonson, Jonsson, Jhonson. "e" was added promiscuously to the end of names, without seemingly affecting the pronunciation. " $y$ " and " $i$ " were interchangeable. To control for this I checked for variant spellings of surnames in 1601-2 and 1851 in determining their status and frequency in 1600 and 1851. Thus, for example, if a name ended in -y, I also checked for the same stem ending in -ie and -ey. If the name had a "ck" I also checked it with only a " $k$ ".

Spelling variants introduce errors, but not errors that should favor the names of the rich versus the poor. We can check this, however, in our data by looking at the relative frequency of spelling variants, versus the originally spelled name in the case of the rich and the poor. This will test whether the names of the rich somehow were more fixed in their original form because of their greater literacy.

Another source of error that cannot be controlled for, is the mutation of surnames over time. ${ }^{23}$ Partly this can occur because of shifts in the way names are pronounced, leading to a later shift in spelling. Thus the wills and court records for 1600 show a ratio of "Clarks" of various stripes of 6:1 with "Clerks." By the 1841 census there were 73,049 "Clarks" and only 835 "Clerks" a ratio of nearly 100:1. Some of the "Clerks" mutated to become "Clarks." "24 Again the errors introduced by such mutations should not tend to favor the rich versus the poor, unless again the names of the literate rich are less subject to mutation.

For 1600 I identify two groups of rare surnames in England 1560-1640. The first was rare surnames held by economically successful men, as revealed by their leaving a will. The second group was rare surnames held by a man on the margins of

\footnotetext{
${ }^{23} \mathrm{As}$ an extreme example, the surnames Birkenshaw, Bircumshaw, Burkimsher, Burtinshall, Brigenshaw, Buttonshaw, Brackenshaw, Buttinger, and Bruckshaw all apparently stem from the place name Birkenshaw (McKinley, 1990, 55).

${ }^{24}$ Presumably because the pronunciation of clerk in modern English is clark.
} 
society, someone indicted in the Essex courts in the years 1598-1620 for assault, burglary, theft, poaching, robbery and murder. The indicted were overwhelmingly from low socio-economic groups. The average man holding the same rare surname as a wealthy man in 1600 will be relatively wealthy. ${ }^{25}$

I get a sample of rare surnames held by rich men in 1560-1639 from a database of 2,445 wills probated in these years, mainly in the counties of Essex and Suffolk. ${ }^{26}$ 689 of these men, 28 percent, had names which did not appear on the parish registers lists for 1601-2, and thus were rare names. We can further divide these testators with rare names into rich (bequest of $£ 250$ or more), middling ( $£ 25-250)$, and poor ( $\left.f^{0-25}\right)$, where wealth is measured in 1630 s prices.

Those leaving wills represent the upper end of the social scale and asset distribution in pre-industrial societies. Identifying rare surnames held by men in the poorest social strata is more difficult. Most tax lists for pre-industrial England identify the propertied. The civil and manorial court records again tend to identify individuals with property to transact or dispute. One place where the poor do show up, however, is in criminal indictments. As in modern societies those accused of theft, forgery, assault, riot, robbery, murder, and desertion were disproportionately the poor.

For the reason that I am attempting to get a sample of the poorest and most violent, I excluded from this sample men indicted for what were crimes against regulations in restraint of trade, or of religious orthodoxy: keeping an unlicensed alehouse, baking without license, erecting cottages on less than 4 acres of land, and recusancy. From this sample of 1,523 indicted men, we get 374 ( 25 percent) who have rare surnames, a similar percentage to that for the sample of will writers.

In the resulting smaller samples there are some names that occur more than once among both the indicted and the will writers. Names with multiple occurrences

\footnotetext{
25I can confirm the validity of the premise that holders of rare surnames tended to have correlated wealth or status, using data on wealth at death in the period 1580-1640. The wealth of those with rare names is correlated. The wealth of those with common names is uncorrelated.

${ }^{26}$ Clark and Hamilton, 2006, describe how these data are constructed from the raw will transcripts. The will sample mainly derives from transcripts in Allen, 1989, 1995, Allen and Evans, 1986a, 1986b, Emmison, 1994-20001, and Evans, 1987, 1993.
} 
in 1600 also tend to appear with greater frequency in 1851, because they were always more common. In the statistical tests below, I include each occurrence of such names as an observation. Otherwise the size of the initial sample matters in terms of the median frequency of the occurrence of names later. Smaller samples will contain proportionately more common names, and have higher median numbers later. Since I have unmatched sample sizes this is undesirable.

Table 14 shows a random sample of 10 percent of the names of the indicted and of 5 percent of the names of the rich, constructed by arranging them in alphabetical order and selecting each $10^{\text {th }}$, or $5^{\text {th }}$, name. As can be seen the names seen very similar in form, and otherwise undistinguishable.

\section{TABLE 14 HERE}

The men in the two resulting samples are from very different ends of the social spectrum. Table 15, for example, shows the distribution of the occupations of 494 men leaving estimated assets of at least £250 in England 1560-1640, compared to the distribution for 1,523 men indicted in Essex courts 1598-1620 for property crimes, assault and homicide. $54 \%$ of the indicted were classified as laborers or the equivalent, compared to $0.2 \%$ for the rich. Overall the bottom four social groups were $6 \%$ of the rich, $81 \%$ of the indicted. ${ }^{27}$

\section{TABLE 15 HERE}

We saw in table 15 the very different occupational distribution for each group around 1600. What is the occupational distribution of their descendants by 1851 revealed by the census, seven generations later? In line with the earlier results for 1300-1600 on common names, there seems to be almost complete regression to the mean. Table 16 shows the socioeconomic status of a sample of adult men of both name groups, taken from the names with the less frequent occurrences. While those descended from the rich show a slightly greater percentage in the top socioeconomic groups, that result may well be sampling error. And at the bottom of the

27 Those accused only of petty larceny were on average even lower in the social scale. $61 \%$ of them were laborers or the equivalent. 
socio-economic scale, there are more of the descendants of the rich among "laborers" than there are descendants of the indicted.

\section{TABLE 16 HERE}

If we compare these results to occupational distributions of England as a whole we find both groups have regressed to the mean. They are indistinguishable from each other and from the population as a whole. This implies both great downward mobility among the descendants of the rich, and modest upward mobility among the descendants of the indicted. The fraction of the descendants of the indicted among the lowest social group, laborers, declined from 54 percent circa 1600 to 29 percent in 1851.

\section{The Rewards of Wealth, 1600-1851}

A Farewell to Alms argued that for 800 years at least in pre-industrial England the rich were taking over the society demographically, and replacing the poor. The evidence above of the dominance of regression to the mean may seem to contradict that argument. But there is no conflict. The rich can still have a reproductive advantage within each generation. It is just that the rich change from generation to generation under the forces of regression to the mean. But if the argument of $A$ Farewell to Alms is correct then the rich in 1600, or in any generation, should have many more descendants by 1851 than the poor, even though by 1851 they are no longer distinguishable by occupation, income, or wealth.

While there was complete regression to the mean in terms of economic status, we do observe that the rich of 1600 left many more descendants than the poor. Though there was geographic mobility in the English population in the pre-industrial era, people holding rare surnames in 1851 related to those we observe circa 1600 would tend to live close to their ancestors. Figure 10, for example, shows the distribution of people with the rare surname "Benefield" in 1881. As can be seen this population is concentrated in east Kent and the nearby city London.

FIGURE 10 HERE 
The data for the indicted is taken from Essex, and most of the wills come from Essex or the adjacent county Suffolk. Figure 11 shows these two counties, as well as the set of adjacent counties. Surrey was included as adjacent even though it is not contiguous to Essex, because the big destination of out migration of people from Essex and Suffolk before 1841 was the London area, part of which lay south of the river Thames in Surrey. In 1841 these eight counties had 28 percent of English population.

\section{FIGURE 11 HERE}

Under the hypothesis is that the differential survival and spread of rare surnames by the rich of 1600 is caused by the differential reproductive success of groups of people genetically related, then this effect should be strongest if we concentrate on the South-East. By doing that we will be concentrating on the people in 1851 most likely to be actually related to the men in the 1600 samples, as opposed to be related by orthographic accident.

Table 17 shows the results for the medians frequency of each name group in the South-East in 1851. The median number of occurrences of the names of the rich by 1851 is 7 times as great as for the indicted. In contrast in the country outside the South-East the difference in name occurrence by 1851 between the will makers and the indicted, while still present, is muted. Rare names of the rich show only twice the median number of occurrences as the rare names of the indicted. Table 18 shows these results.

\section{TABLES 17, 18 HERE}

To test the statistical significance of the median differences reported in table 14 I carry out two tests. The first looks just at the differences in the medians, and is a non-parametric test of the hypothesis that two samples were drawn from a distribution with the same median. The chances that by 1851 the names in each of the three wills samples have the same median number of occurrences as the indictments sample is always less than 1 percent. The second test, that of Mann and Whitney, looks not just at the medians, but the whole rank of the observations. This tests not just the median, but whether the samples are from populations with the same distribution of values. This test rejects even more strongly the possibility that 
the distribution of frequencies for the names of the indicted by 1851 is the same as that for any of the will samples.

Might the indicted have been significantly more likely to deliberately change their name, perhaps to escape social census of the long arm of the law? We saw above the surprising frequency of "smiths" among the criminal classes, including this group in 1600. But the extent of deliberate name changes required to produce the differences in name frequencies is implausibly large.

I can also test whether the names of the rich adhered to them better because they could write, and thus the name would mutate less over time. To test this I look at the fraction of matches for each name in 1851 that were exact matches to the earlier name as opposed to just similar sounding matches (Adwicke as the original, for example, compared to the similar sounding Adwick or Addwick). Table 19 shows the results of this test for the names of the indicted and the will makers using cases where there were less than 300 bearers of the name in any spelling by 1851 . The names of the rich were just as likely to be found in variant spellings from that originally observed as were the names of the indicted. Thus there is no evidence that the names of the poor were any more mutable than those of the rich.

\section{TABLE 19 HERE}

The implication is simple. Economic success by a man in 1600 substantially increased his share of their genes in the English gene pool by 1851, as was predicted in A Farewell to Alms. The genes of the English in 1851 were composed disproportionately of those who succeeded economically in the pre-industrial era. This can also explain the decline in the frequency of "artisan" surnames after the fourteenth century. As initially a lower income group within the population they would have less reproductive success than other higher income groups, and thus see a decline in the share of their surnames among the population. 


\section{Conclusion}

The evidence above suggests that England was likely a classless society of complete long run social mobility all the way from 1200 to 2009. This is true for the indigenous population, and for at least some immigrant groups. The strength of regression to the mean may have changed over time and that has still to be determined. Whether complete mobility remains true for all subgroups in the UK population has still to be determined. But there are signs that this may not be universally true. Muslim immigrants from the Indian subcontinent, for example, have lower earnings now than Hindu immigrants. What is surprising about this early mobility is that it occurred in a society where, unlike ours, there was little or no public support for education. There was also no legal barrier to nepotism and exploitation of familial connections.

Complete social mobility and the absence of persistent social classes is not true of the modern USA where at least two groups - Blacks and Jews - have, as table 1 shows, not shown regression to the mean. There are also some indications that immigrants from Mexico and Central America are not regressing to the mean (in terms of such characteristics as educational attainment). In other societies such as Brazil surnames of German and Japanese origin are still disproportionately represented in the membership rolls of elite groups generations after substantial immigration to the country by those nationalities ended.

The last tantalizing question is what the universal regression to the mean observed in England implies about the sources of economic success. For individuals we can think of economic success, measured as the log of wealth, $y$, as having two components: genetically transmitted talents, $t$, and human capital, $h$. Thus

$$
y_{0}=\theta t_{0}+(1-\theta) h_{0}+u_{0}
$$

where $\theta$ is the share of success determined by genes, and $(1-\theta)$ the share determined by human capital. The distinctive feature of the transmission of the genetic component, talent, between generations is that it always involves regression to the mean, because of less than perfect assortative mating. The transmission of human capital does not involve any such necessary regression to the mean. The educated 
can ensure that their children have just as much, or more, human capital that they have. Thus

$$
\begin{aligned}
& t_{1}=b t_{0}+e_{0} \\
& h_{1}=h_{0}+v_{0}
\end{aligned}
$$

The genetic component of success gets transmitted imperfectly, but the human capital element can be passed on undiminished. This in turn implies that

$$
\begin{gathered}
y_{1}=\theta b t_{0}+(1-\theta) h_{0}+u_{1} \\
y_{2}=\theta b^{2} t_{0}+(1-\theta) h_{0}+u_{2} \\
\ldots \ldots \ldots \ldots \ldots \ldots \\
y_{n}=(1-\theta) h_{0}+u_{n}
\end{gathered}
$$

Thus the existence of complete long run social mobility seems to suggest that the overwhelming source of economic success is not the perfectly reproducible human capital, but instead the genetics of talent.

One puzzle remains, however, which is that the data in the paper suggest that individual family histories such as that of the Stanley Earls of Derby, at the top of the income distribution for 29 generations, are statistically of extreme improbability. Their success over 900 years implies that at least at the very top of traditional English society there must be some limitation on regression to the mean. In this case it may be that there was one indivisible and undiminishable attribute that got passed from one generation to the next, which was the indivisible title, the Earldom itself. 


\section{Archival Sources}

UK, Census, 1851. Available online at

http://www.nationalarchives.gov.uk/records/census-records.htm

Earls Colne: Records of an English Village 1375-1854.

http://linux02.lib.cam.ac.uk/earlscolne/probate/index.htm

Index to the Prerogatory Court of Canterbury Wills, 1384-1858. (UK National Archives,

London).

The Proceedings of the Old Bailey, 1674-1913. http://www.oldbaileyonline.org/index.jsp

\section{Other Data Sources}

Allen, Marion E. 1989. Wills of the Archdeaconry of Suffolk, 1620-24. Suffolk Records Society, Volume 21. Woodbridge, Suffolk: The Boydell Press.

Allen, Marion E. 1995. Wills of the Archdeaconry of Suffolk, 1625-26. Suffolk Records Society, Volume 37. Woodbridge, Suffolk: The Boydell Press.

Allen, Marion E. and Nesta Evans. 1986a. Wills of the Archdeaconry of Suffolk, 16291636. Boston: New England Historic Genealogical Society.

Allen, Marion E. and Nesta Evans. 1986b. Wills of the Archdeaconry of Suffolk, 1637 1640. Boston: New England Historic Genealogical Society.

Cockburn, J. S. 1978. Calendar of Assize Records, Essex Indictments, Elizabeth I. London: Her Majesty's Stationary Office.

Cockburn, J. S. 1982. Calendar of Assize Records, Essex Indictments, James I. London: Her Majesty's Stationary Office.

Emmison, F. G. 1990-2004. Essex Wills, 1558-1603. Volumes 1-11. Chelmsford: Essex Record Office.

Evans, Nesta. 1987. The Wills of the Archdeaconry of Sudbury, 1630-35. Suffolk Records Society, Vol. 29. Woodbridge, Suffolk: The Boydell Press.

Evans, Nesta. 1993. The Wills of the Archdeaconry of Sudbury, 1636-38. Suffolk Records Society, Vol. 35. Woodbridge, Suffolk: The Boydell Press, 1993.

Fenwick, Carolyn C. 2001. The poll taxes of 1377, 1379 and 1381. Part 2: Lincolnshire to Westmorland. Oxford: Oxford University Press for the British Academy.

Great Britain General Registrar Office. 1856. Annual report of the registrar-general of births, deaths, and marriages in England. v. 16, 1853. London.

Hitching, F. K. and S. Hitching. 1910. References to English Surnames in 1601. Waltonon-Thames: Charles Bernau. 
Hitching, F. K. and S. Hitching. 1911. References to English Surnames in 1602. Waltonon-Thames: Charles Bernau.

Public Record Office. 1904. Calendar of Inquisitions Post Mortem and other Analogous Documents preserved in the Public Record Office, Vol. 1 Henry III. London: Public Record Office.

Public Record Office. 1906. Calendar of Inquisitions Post Mortem and other Analogous Documents preserved in the Public Record Office, Vol. 2 Edward I. London: Public Record Office.

\section{References}

Becker, Gary. 1988. "Family Economics and Macro Behavior." American Economic Review, 78: 1-13.

Becker, Gary and Nigel Tomes. 1986. "Human Capital and the Rise and Fall of Families." Journal of Labor Economics, 4(3): S1-S39.

Biblarz, Timothy J., Vern L. Bengtson and Alexander Bucur. 1996. "Social Mobility Across Three Generations." Journal of Marriage and the Family, 58(1): 188-200.

Bowles, Samuel. 2007. “Genetically Capitalist?” Science, 318 (Oct 19): 394-5.

Bowles, S. and H. Gintis. 2002. "The Inheritance of Inequality” Journal of Economic Perspectives. Volume 16, Number 3, 1 August 2002, pp. 3-30(28)

Clark, Gregory. 2007. A Farewell to Alms: A Brief Economic History of the World. Princeton: Princeton University Press.

Clark, Gregory. 2008. "In Defense of the Malthusian Interpretation of History." European Review of Economic History, 12(2) (August).

Clark, Gregory and Gillian Hamilton. 2006. "Survival of the Richest. The Malthusian Mechanism in Pre-Industrial England." Journal of Economic History, 66(3) (September): 707-36.

Galton, Francis 1869. Hereditary Genius: An Enquiry into its Laws and Consequences. London: Macmillan and Co.

Galton, Francis. 1877. “Typical laws of heredity." Proceedings of the Royal Institution 8: 282-301

Galton, Francis 1886. "Regression Towards Mediocrity in Hereditary Stature". Journal of the Anthropological Institute of Great Britain, 15: 246-263.

Güell, Maia, José V. Rodríguez Mora, and Telmer, Chris. 2007. "Intergenerational Mobility and the Informative Content of Surnames." Working Paper, Edinburgh University. 
Harbury, C. D. and Hitchens, D. M. W. N. 1979. Inheritance and Wealth Inequality in Britain. London: Allen and Unwin.

Herrnstein, Richard J. and Charles Murray. 1996. The Bell Curve: Intelligence and Class Structure in American Life. New York: Free Press.

Hertz, Thomas. 2005. "Rags, Riches and Race: The Intergenerational Mobility of Black and White Families in the United States" in Samuel Bowles, Herbert Gintis and Melissa Osborne (eds.), Unequal Chances: Family Background and Economic Success, 165-191. New York: Russell Sage and Princeton University Press.

Jobling, Mark A. 2001. "In the name of the father: surnames and genetics." TRENDS in Genetics, Vol. 17, No. 6 (June): 353-357.

King, Turi E., Stéphane J. Ballereau, Kevin E. Schürer, and Mark A. Jobling. 2006. "Genetic Signatures of Coancestry within Surnames." Current Biology, 16 (21 February): 384-388.

Long, Jason and Joseph Ferrie. 2009. "Intergenerational Occupational Mobility in Britain and the U.S. since 1850." Working Paper, Colby College, Maine.

McCloskey, Deirdre. 2008. "You know, Ernest, the rich are different from you and me: A comment on Clark's Farewell to Alms." European Review of Economic History, 12(2) (August).

McKinley, Richard A. 1975. Norfolk and Suffolk surnames in the Middle Ages. London: Phillimore.

McKinley, Richard A. 1990. A History of British Surnames. Longman: London. Orwell, George. 1941. The Lion and the Unicorn: Socialism and the English Genius. London: Secker \& Warburg.

Pomeranz, Kenneth. 2008. "Featured Review: A Farewell to Alms" American Historical Review, 113(3) (June): 775-779.

Rogers, Colin D. 1995. The Surname Detective: Investigating Surname Distribution in England, 1086-Present Day. Manchester: Manchester University Press.

Solon, G. 1999. "Intergenerational mobility in the labor market," in Handbook of Labor Economics, Vol. 3A, Orley C. Ashenfelter and David Card (eds.), Amsterdam: Elsevier.

Wasson, E. A. 1998. "The Penetration of New Wealth into the English Governing Class from the Middle Ages to the First World War." The Economic History Review, New Series, Vol. 51, No. 1 (Feb.): 25-48.

Watson, H. W. and Francis Galton. 1875. "On the Probability of the Extinction of Families", Journal of the Anthropological Institute of Great Britain, 4: 138-144. 
Wrigley, E. A. and R. S. Schofield. 1981. The population history of England, 1541-1871 : a reconstruction. Cambridge: Cambridge University Press. 
Figure 1: Regression to the mean in income illustrated

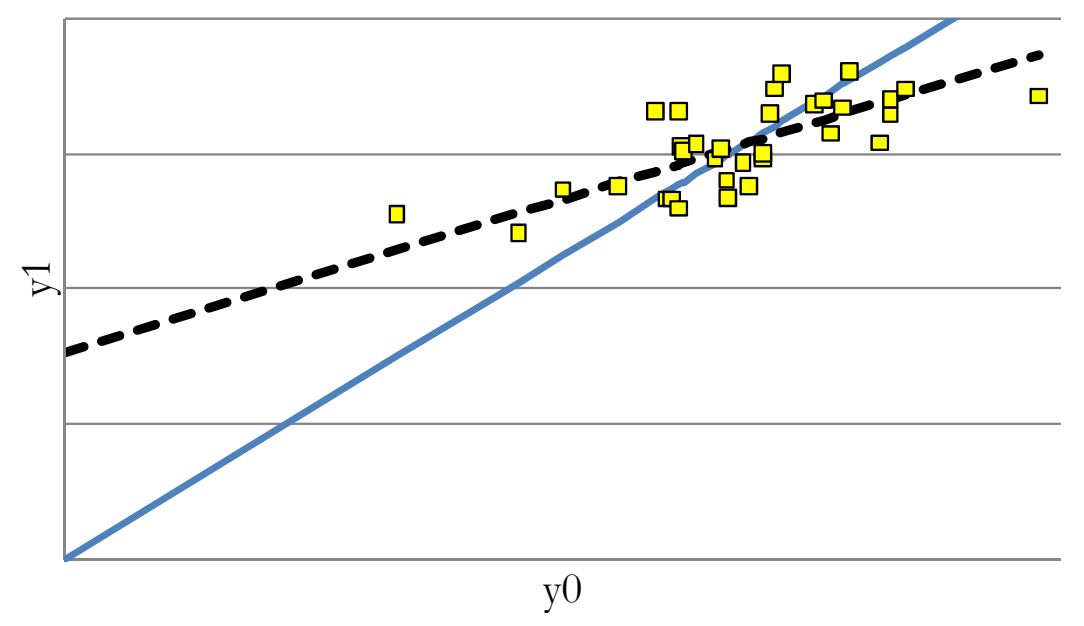


Figure 2: Regression to the Mean by generation

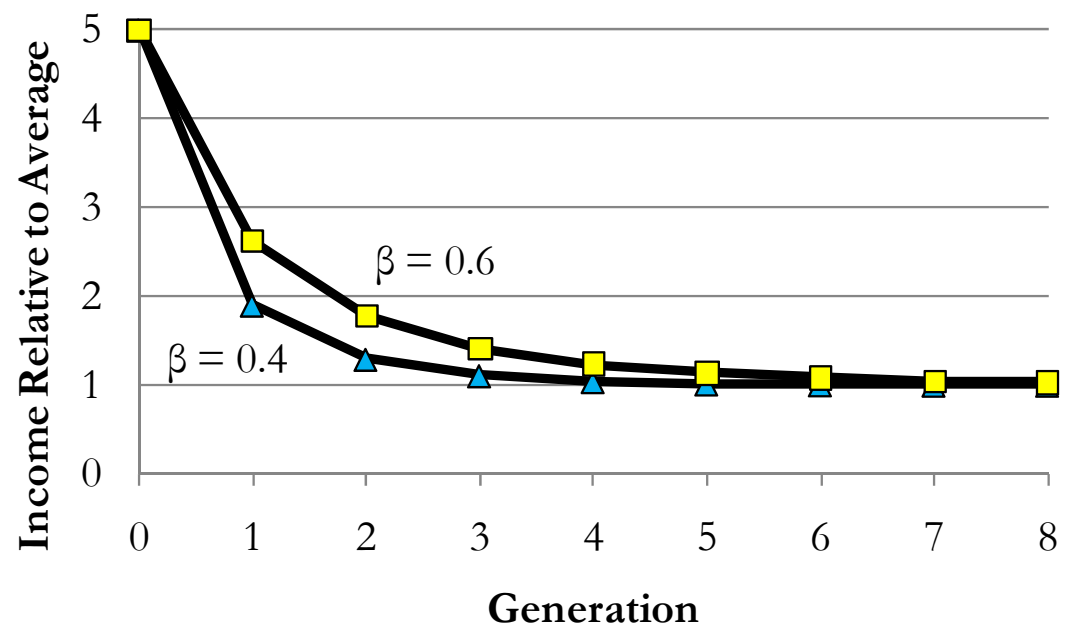


Figure 3: Regression to the mean with different social classes

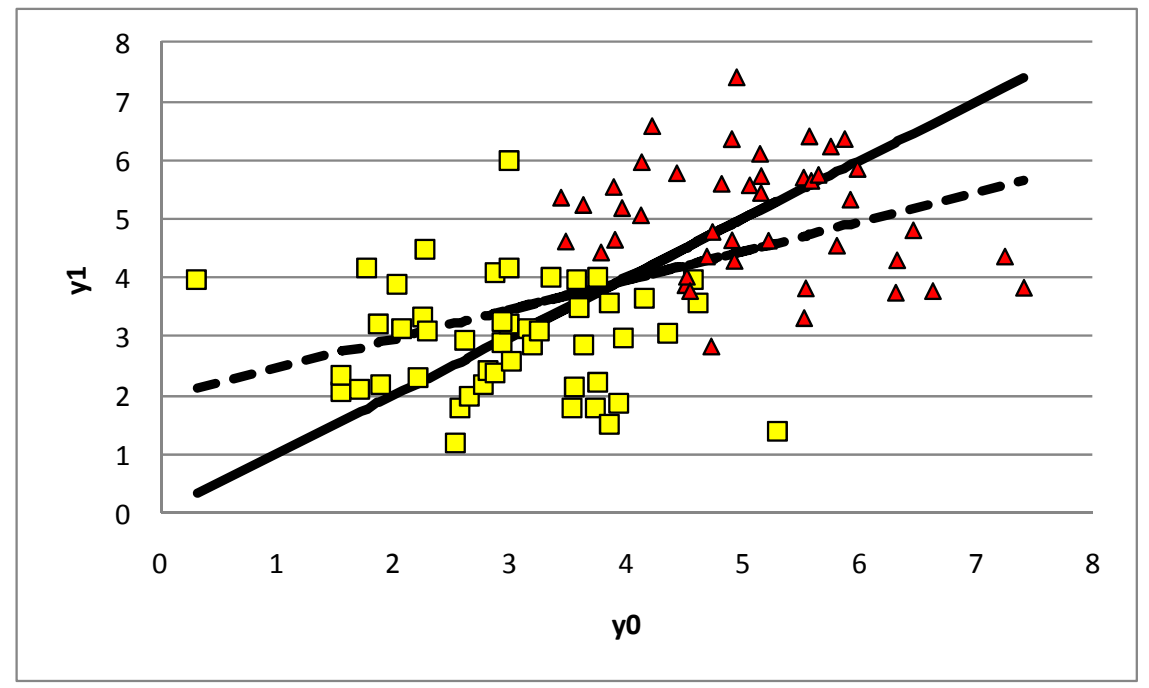


Figure 4: Percent Lower Class Artisan Names in Prerogative Court of Canterbury Wills

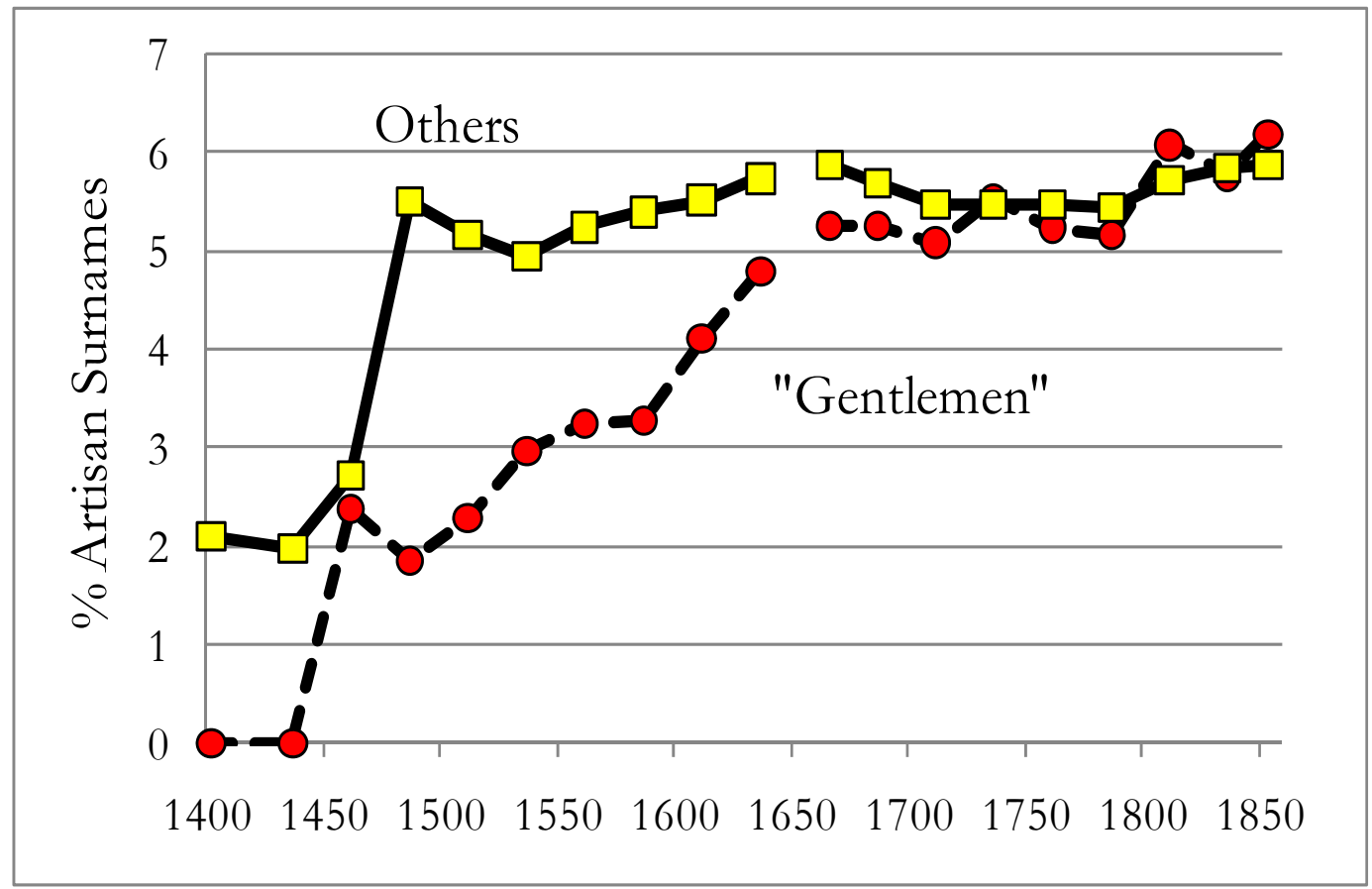

Source: Index to the Prerogatory Court of Canterbury Wills. 
Figure 5: Simulated share of artisans at the top of the wealth distribution if they started at the $33^{\text {rd }}$ percentile.

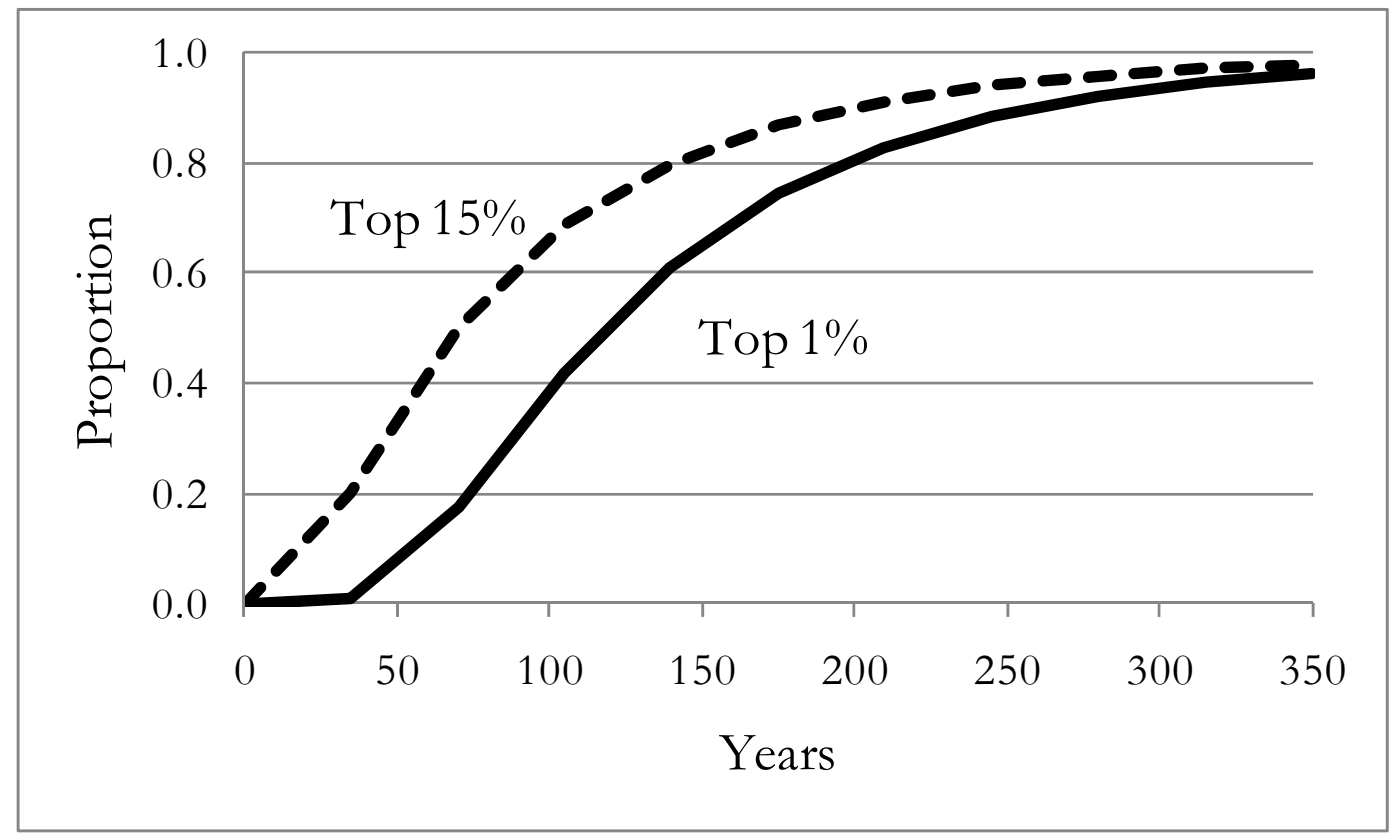

Note: A generation is assumed to be 35 years. 
Figure 6: Artisan Names in the York Courts Wills

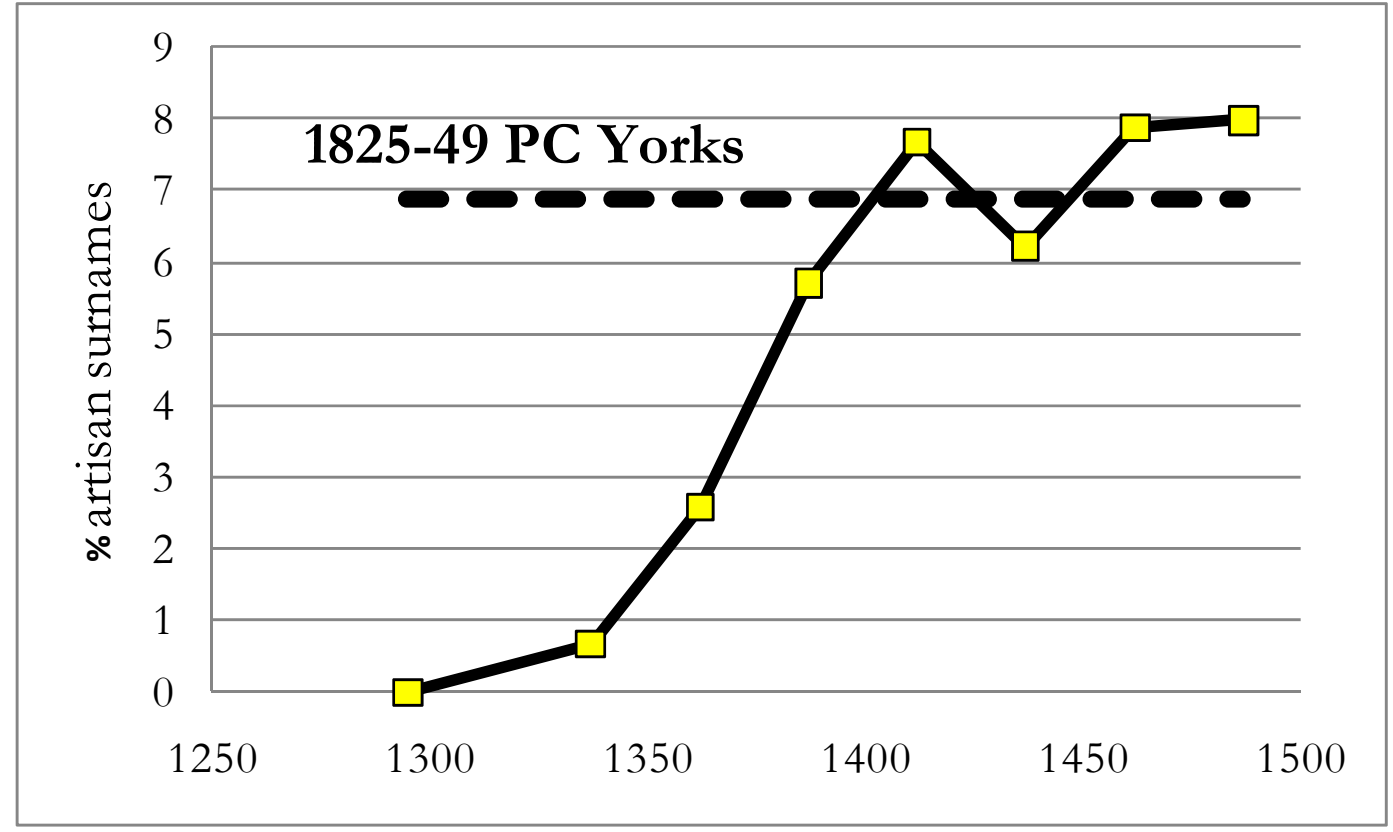

Source: Index of the Exchequer and Prerogative Courts of York, Borthwick Institute, York. 
Figure 7: Relative Frequency of the Surnames of the Medieval Elite among the Rich and among Criminals, 1236-1858

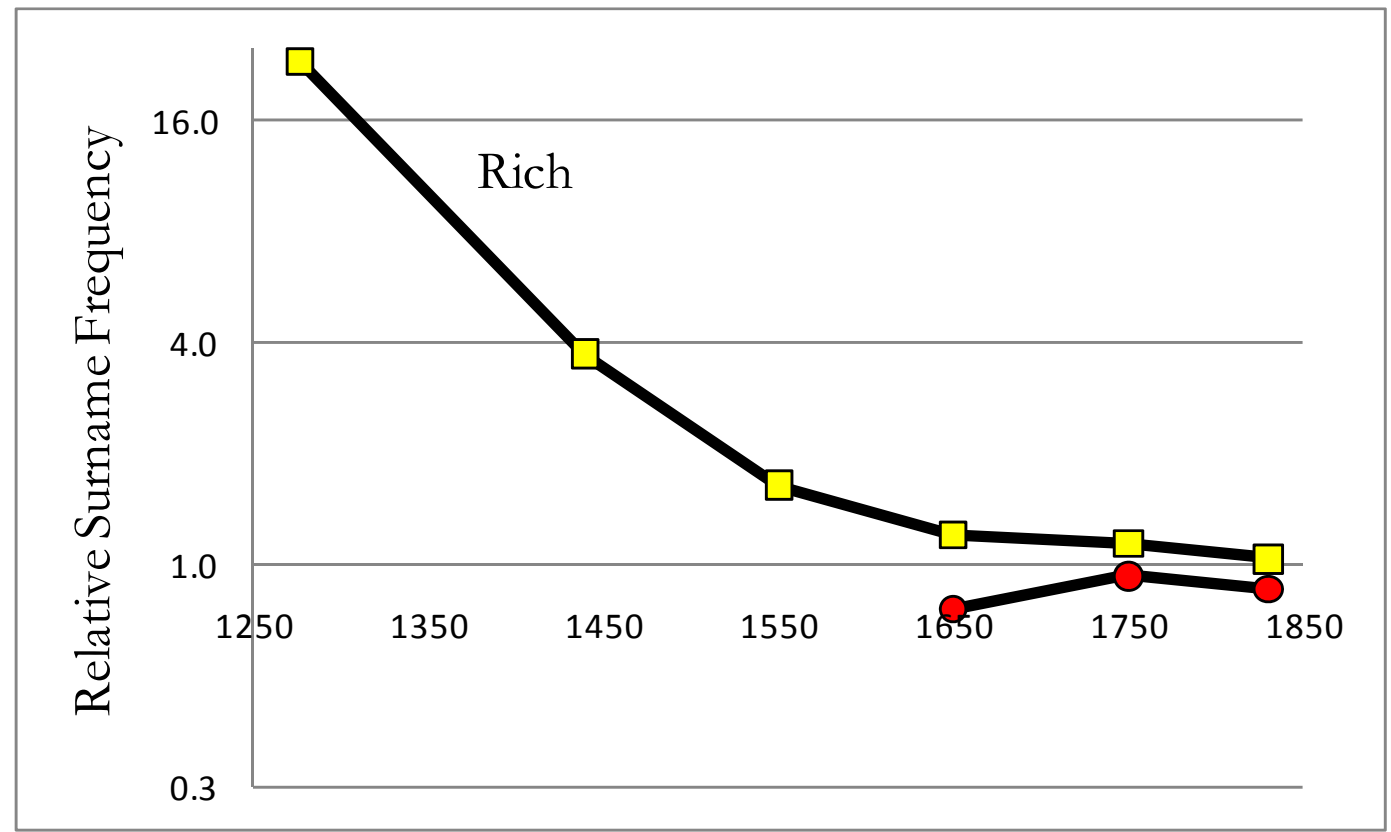

Note: The vertical axis has a logarithmic scale. The upper line shows the relative frequency of the surnames of the medieval elite among the wealthy compared to their share in the general population. The lower line shows the relative frequency of the surnames of the medieval elite in the accused of the Old Bailey compared to victims of crimes. For 1236-99 the frequency of the medieval elite's surnames in the general population is assumed to be the same as in 1380-1499.

Sources: Index to the Prerogatory Court of Canterbury Wills. The Proceedings of the Old Bailey. Fenwick (2001). Public Record Office $(1904,1906)$. 
Figure 8: Estimated b coefficients for people of same rare surname between 1858-79 and later generations.

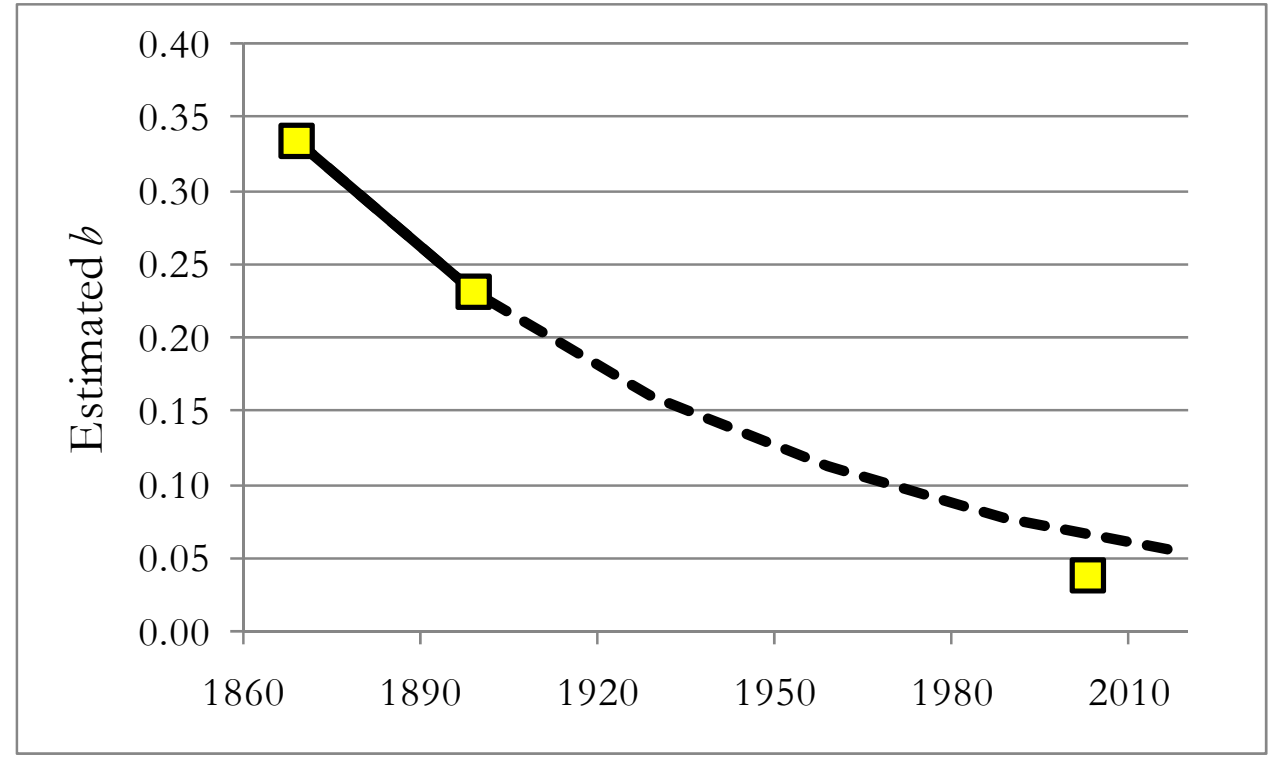

Figure 9: The Connection Between Average Wealth by Surname, 1858-2009 and 1996-2010

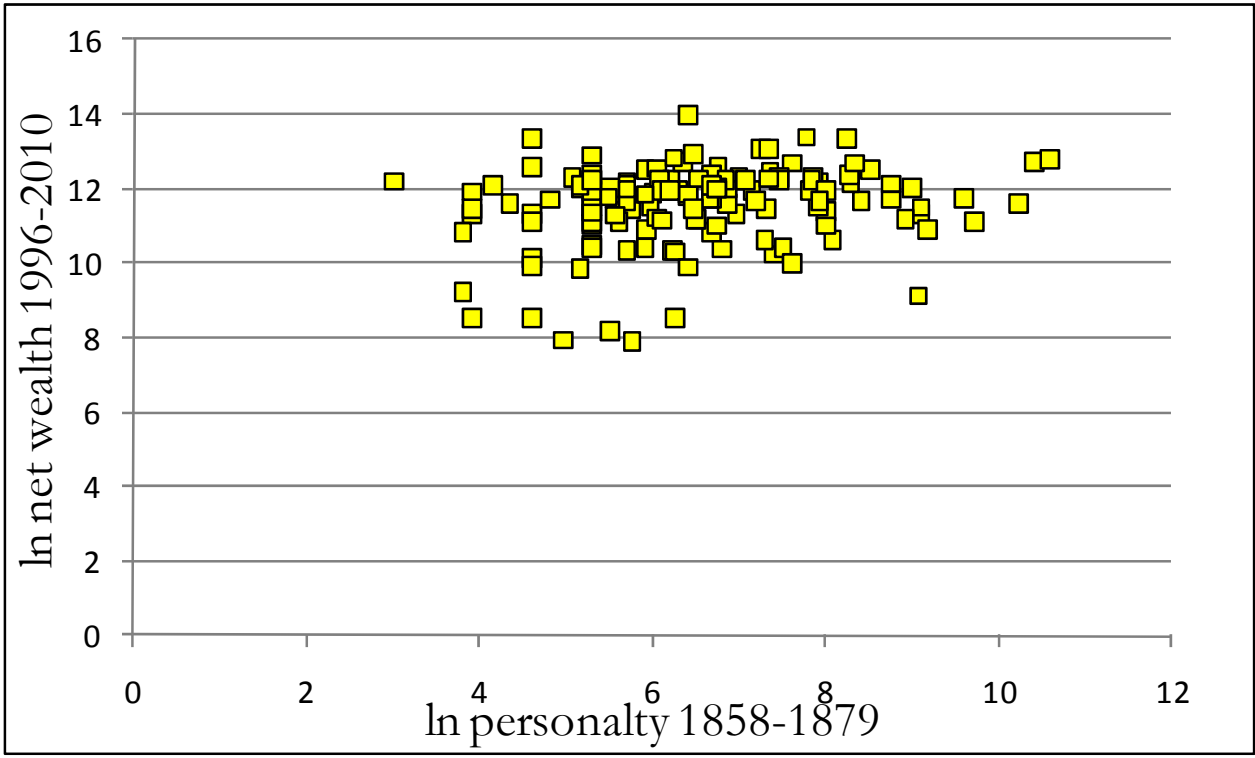


Figure 10: Distribution of the surname "Benefield" in 1881

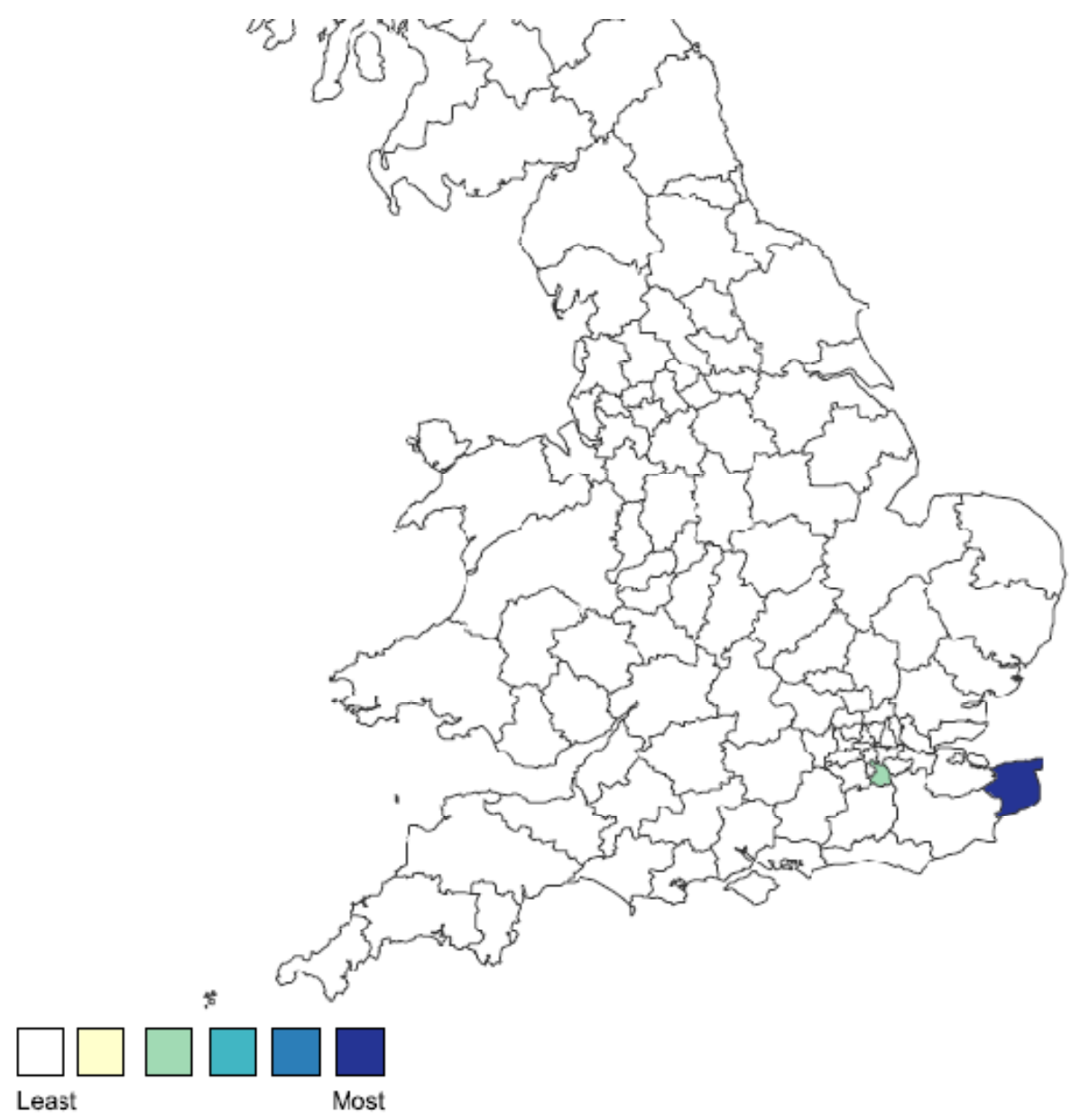

Source: National Trust, UK. Surname location database, created from the 1881 UK census. Available online at http://www.nationaltrustnames.org.uk/Surnames.aspx. 
Figure 11: English Counties in 1841

Figure 1: English Counties in 1841

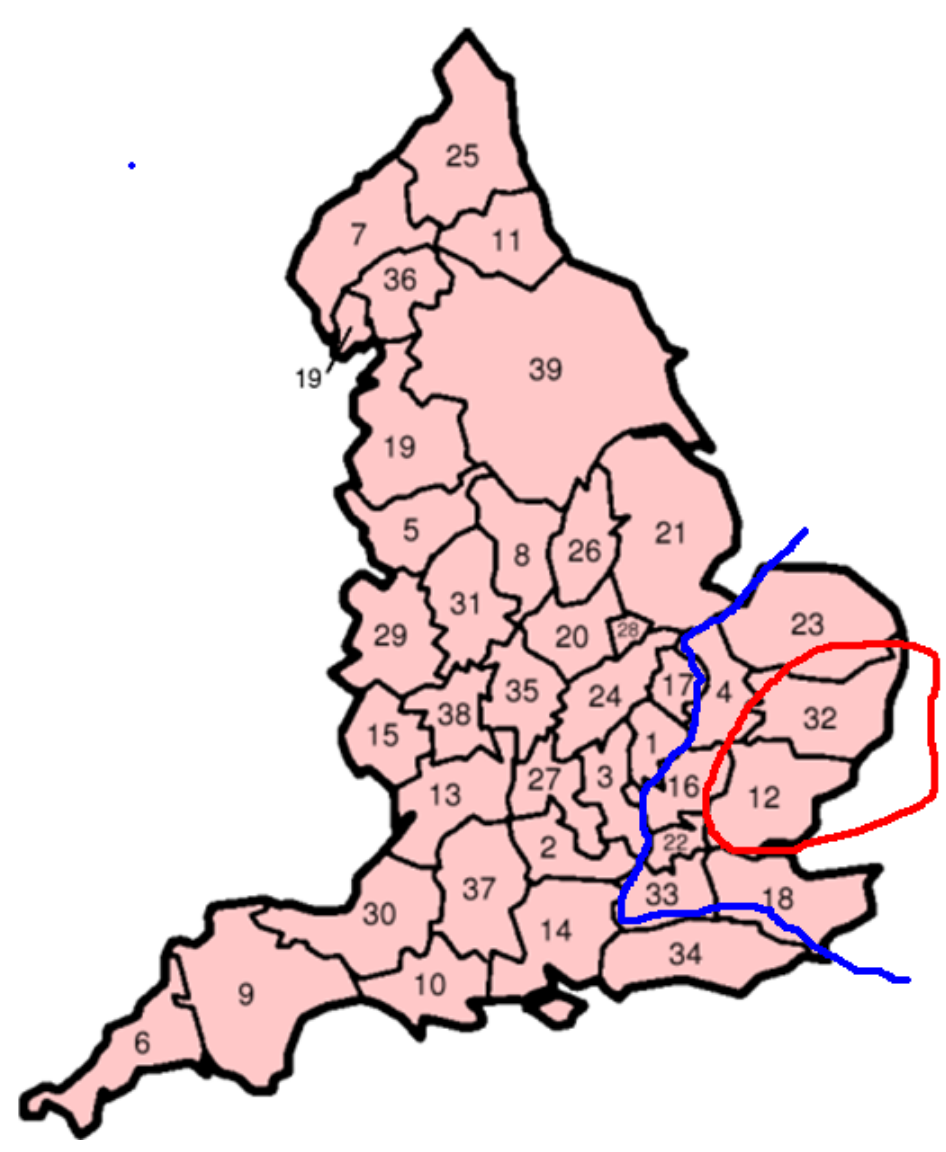

Notes: Suffolk $=32$, Essex $=12$ (adjacent counties are Norfolk (23), Cambridge (4),

Hertford (16), Middlesex (22), Surrey (33) and Kent (18)).

Source: This map is reproduced from

http://en.wikipedia.org/wiki/Historic_counties_of_England. 
Table 1: Regression to the mean controlling for race, USA

\begin{tabular}{|c|c|c|c|}
\hline Independent Variable & $\begin{array}{c}\text { No } \\
\text { controls }\end{array}$ & Only Race & $\begin{array}{c}\text { All Observable Parenta } \\
\text { Characteristics }\end{array}$ \\
\hline $\begin{array}{l}\text { Ln Family Income of } \\
\text { Parents }\end{array}$ & $0.52^{* *}$ & $0.43^{* *}$ & $0.20^{* *}$ \\
\hline Black & - & $-0.33^{* *}$ & $-0.28^{* *}$ \\
\hline Latino & - & $-0.27 * *$ & -0.15 \\
\hline Jewish & - & - & $0.33^{* *}$ \\
\hline \multicolumn{4}{|c|}{$\begin{array}{l}\text { Notes: } * *=\text { significant at the } 1 \text { percent level. Only } 3 \text { percent of the sample was } \\
\text { Latino. } \\
\text { Source: Hertz, } 2005 \text {, table } 6 .\end{array}$} \\
\hline Type of Surname & Exa & ples & $\begin{array}{c}\text { Percent Taxpayers } \\
1327-32\end{array}$ \\
\hline Locative & Walsham, Pake & am, Merton & 27 \\
\hline Toponymic & Hill, Green, Wc & d, Lane & 13 \\
\hline Patronymic & Williamson, Wi & n, Adams & 20 \\
\hline Nicknames & Brown, White, & ttle, Hardy & 19 \\
\hline Occupations & Smith, Taylor, & ight, Baxter & 10 \\
\hline Other & & & 11 \\
\hline
\end{tabular}

Source: McKinley, 1990, 23. 
Table 3: Surnames of the rich, 1236-1299

\begin{tabular}{lccc}
\hline & & & \\
Type of & Subclass & Number & Percent of \\
Surname & & & surnames \\
& & & \\
\hline & & & \\
Locative & - & 1,598 & 74.7 \\
Toponymic & - & 4 & 0.2 \\
Patronymic & - & 18 & 0.8 \\
Nicknames & - & 44 & 2.1 \\
Occupations & higher status & 36 & 1.7 \\
Occupations & artisan and lower & 8 & 0.4 \\
Other/Unknown & - & 430 & 20.1 \\
No Surname & - & 159 & \\
& & & - \\
\hline
\end{tabular}

Source: Public Record Office, 1904, 1906.

Table 4: Surnames 1381 Poll Tax, Suffolk

\begin{tabular}{lcc}
\hline Type of Surname & Number & Percent \\
& & \\
\hline & & \\
Locative & 149 & 9.6 \\
Toponymic & 72 & 4.6 \\
Patronymic & 91 & 5.8 \\
Nicknames & 92 & 5.9 \\
Occupations -high status & 37 & 2.4 \\
Occupations - artisans & 233 & 14.9 \\
Other/Unknown & 886 & 56.8 \\
& & \\
All & 1,560 & 100 \\
\hline
\end{tabular}

Source: Fenwick, 2001. 
Table 5: Distribution of Prerogative Court of Canterbury Wills

\begin{tabular}{llll}
\hline Century & PCC wills & $\begin{array}{l}\text { Population } \\
\text { (millions) }\end{array}$ & Wills/year/death \\
\hline & & & \\
$1384-99$ & 87 & 2.5 & .0002 \\
$1400-99$ & 5,915 & 2.3 & .002 \\
$1500-99$ & 45,555 & 3.3 & .010 \\
$1600-99$ & 218,624 & 5.2 & .029 \\
$1700-99$ & 361,827 & 6.7 & .040 \\
$1800-58$ & 384,119 & 14.6 & .036 \\
& & & \\
\hline
\end{tabular}

Source: Index to the Prerogatory Court of Canterbury Wills. 
Table 6: Surname Type Frequencies

\begin{tabular}{lccc}
\hline \multicolumn{1}{c}{ Group } & Number & $\begin{array}{c}\text { Percent } \\
\text { “Smith" }\end{array}$ & $\begin{array}{c}\text { Percent Other } \\
\text { Artisan Names }\end{array}$ \\
& & & \\
& 1,560 & 1.6 & 9.2 \\
Suffolk, 1381, Poll Tax & - & 1.4 & 3.8 \\
England, all, 1853 & 66,807 & 1.3 & 4.0 \\
PCC wills, 1850-8 & 15,705 & $3.0^{\mathrm{a}}$ & 4.1 \\
London, indicted, 1850-9 & & & 3.9 \\
& 31,690 & 1.2 & 4.1 \\
PCC wills, 1600-24 & 1,262 & $1.7^{\mathrm{a}}$ & 4.4 \\
Indicted Laborers, Essex, 1559-99 & 891 & $2.2^{\mathrm{a}}$ & \\
Indicted Laborers, Essex, 1600-25 & & & \\
& & & \\
\hline
\end{tabular}

Notes: "The share of "smiths" among the indicted is always unexpectedly high, presumably because some criminals use alias's, and in doing so choose the most common name. This table is drawn using a smaller set of artisan surnames than in figures 4 and 6.

Sources: Fenwick, 2001, Annual Report of the Registrar General, 1856, Index to the Prerogatory Court of Canterbury Wills, The Proceedings of the Old Bailey, Cockburn, 1978, 1982. 
Table 7: Surname Frequencies of the Medieval Upper Class

\begin{tabular}{lccc}
\hline Period & $\begin{array}{c}\text { Share Wealthy } \\
\mathbf{( \% )}\end{array}$ & $\begin{array}{c}\text { Share All } \\
\mathbf{( \% )}\end{array}$ & $\begin{array}{c}\text { Relative } \\
\text { Frequency } \\
\text { Wealthy }\end{array}$ \\
& & & \\
$1236-99$ & 10.43 & $(0.45)$ & 23.23 \\
$1380-1499$ & 1.67 & 0.45 & 3.73 \\
$1500-99$ & 0.90 & 0.55 & 1.64 \\
$1600-99$ & 0.69 & 0.57 & 1.21 \\
$1700-99$ & 0.67 & 0.58 & 1.15 \\
$1800-58$ & 0.61 & 0.59 & 1.04 \\
\hline
\end{tabular}

Note: Set of wealthy defined $1236-99$ as those with Inquisition Post Mortem, and 1380-1858 as those with a PCC will.

Table 8: Medieval Upper Class in Old Bailey Records

\begin{tabular}{cccc}
\hline Period & $\begin{array}{c}\text { Share Accused } \\
\mathbf{( \% )}\end{array}$ & $\begin{array}{c}\text { Share Victims } \\
\mathbf{( \% )}\end{array}$ & $\begin{array}{c}\text { Relative } \\
\text { Frequency } \\
\text { Wealthy } \\
\text { among accused } \\
\text { among }\end{array}$ \\
\hline $1600-99$ & 0.68 & 0.90 & 0.75 \\
$1700-99$ & 0.61 & 0.66 & 0.93 \\
$1800-58$ & 0.47 & 0.55 & 0.86 \\
\hline
\end{tabular}


Table 9: Immigrant Group Surnames in London, 1830-59

\begin{tabular}{lccc}
\hline Surname Group & $\begin{array}{c}\text { PCC wills } \\
\mathbf{( \% )}\end{array}$ & $\begin{array}{c}\text { Old Bailey } \\
\text { Victims }\end{array}$ & $\begin{array}{c}\text { Old Bailey } \\
\text { Accused }\end{array}$ \\
& & $\mathbf{( \% )}$ & $\mathbf{( \% )}$ \\
& & & \\
Artisans & $3.82^{\mathrm{a}}$ & 3.90 & 4.25 \\
Irish & $0.67^{\mathrm{a}}$ & 1.18 & 3.69 \\
Scottish & - & 2.04 & 2.01 \\
\end{tabular}

Note: ${ }^{a}$ The PCC will shares here are for London and Middlesex in the years 1850-8, to partially control for the youth of the Irish immigrant population compared to the general population, and its concentration in urban locations.

Source: Index to the Prerogatory Court of Canterbury Wills. The Proceedings of the Old Bailey

Table 10: The Composition of the 1858-79 Rare Name Sample

\begin{tabular}{cccc}
\hline Year & Unique Surnames & All testators & $\begin{array}{c}\text { Average Frequency } \\
1881 \text { census }\end{array}$ \\
& 270 & 299 & 11.2 \\
$1858-60$ & 13 & & 14.3 \\
$1861-79$ & & 433 & 13.0 \\
$1858-1879$ & 283 & 732 & 16.9 \\
$1888-1909$ & 0 & 527 & 16.8 \\
$1996-2010$ & 0 & 501 & \\
\hline
\end{tabular}


Table 11: b coefficients on wealth and personalty - fathers, sons, brothers 1790-1900

\begin{tabular}{lcc}
\hline & Father-son & Brothers \\
& & \\
\hline Wealth & $0.445^{* *}$ & 0.345 \\
& $(.063)$ & $(.181)$ \\
$\mathrm{N}$ (pairs) & 204 & 28 \\
& & \\
Personalty & $0.273^{* *}$ & $0.383^{* *}$ \\
& $(.076)$ & $(.127)$ \\
$\mathrm{N}$ (pairs) & 154 & 29 \\
\hline
\end{tabular}

\section{Table 12: Estimated b Coefficient Linking Ln Wealth by same} Rare Surname

\begin{tabular}{lccc}
\hline & $1858-79$ & $1888-1909$ & $1996-2010$ \\
\hline \multirow{2}{*}{$1858-79$} & $0.334^{* *}$ & $0.232^{* *}$ & 0.039 \\
& $(.059)$ & $(.041)$ & $(.032)$ \\
$1888-1909$ & - & $0.184^{* *}$ & -0.006 \\
& & $(.047)$ & $(.032)$ \\
$1996-2010$ & - & - & $0.132^{*}$ \\
& & & $(.049)$ \\
\hline
\end{tabular}

Notes: Standard errors in parentheses. ${ }^{* *}$ significant at $1 \%$ level, ${ }^{*}$ significant at the $5 \%$ level. 
Table 14: Fraction of Surnames in Same County

\begin{tabular}{lccc}
\hline & $1858-79$ & $1888-1909$ & $1996-2010$ \\
$1858-79$ & $0.40[.09]$ & 0.29 & $0.10[.06]$ \\
$1888-1909$ & - & 0.27 & 0.11 \\
$1996-2010$ & - & - & 0.17 \\
& & & \\
\hline
\end{tabular}

Note: Surnames were located within the 54 counties in England and Wales in 1851 in all periods. 
Table 14: Rare Names of the Indicted and the Rich in 1600

\begin{tabular}{|c|c|}
\hline Names of the indicted & Names of the Rich \\
\hline Abstan & Aldham \\
\hline Banbricke & Ayliffe \\
\hline Bittin & Base \\
\hline Bradwyn & Birle \\
\hline Cabwell & Breame \\
\hline Cheveney & Bynder \\
\hline Cockle & Cobbold \\
\hline Creame & Coventry \\
\hline Cutmore & Danbrook \\
\hline Drinckall & Fatter \\
\hline Elvis & Folkes \\
\hline Fossett & Gatteward \\
\hline Gillham & Godbold \\
\hline Gullyes & Gooch \\
\hline Heditche & Hazell \\
\hline Hownell & Hunringdon \\
\hline Kenwood & Ilger \\
\hline Los & Kingsberie \\
\hline Meese & Libbis \\
\hline Mounson & Maynerd \\
\hline Nouthe & Negus \\
\hline Osteler & Overed \\
\hline Pennocke & Playfere \\
\hline Pollen & Raynberde \\
\hline Reddyforde & Rosington \\
\hline Sache & Scolding \\
\hline Segrave & Spatchet \\
\hline Shurly & Tokelove \\
\hline Sticinger & Upston \\
\hline \multicolumn{2}{|l|}{ Terlynge } \\
\hline \multicolumn{2}{|l|}{ Thurland } \\
\hline \multicolumn{2}{|l|}{ Uphavering } \\
\hline \multicolumn{2}{|l|}{ Wendham } \\
\hline Wrothman & \\
\hline
\end{tabular}

Source: $10 \%$ random sample of the wills collection rare names, $5 \%$ random sample of the indicted rare surnames. 
Table 15: Occupational Distribution: the Rich and the Indicted c. 1600

\begin{tabular}{lcc}
\hline Social Group & $\begin{array}{c}\text { Bequest of } \\
f^{250} \text { or more } \\
(\%)\end{array}$ & $\begin{array}{c}\text { Indicted } \\
(\%)\end{array}$ \\
& & \\
& & \\
& 17 & 2 \\
Gentry & 8 & 1 \\
Merchants/Professionals & 70 & 6 \\
Farmers/Yeomen & 2 & 9 \\
Traders & 2 & 13 \\
Craftsmen & 2 & 11 \\
Husbandmen & 0 & 54 \\
Laborers & & \\
\end{tabular}

Sources: Wills - Allen, 1989, 1995, Allen and Evans, 1986a, 1986b, Emmison, 19942001, Evans 1987, 1993. Indicted - Cockburn, 1978, 1982. 
Table 16: Socioeconomic Status by Surname History, 1851

\begin{tabular}{lcc}
\hline Status, 1851 & $\begin{array}{c}\text { Rich in 1600 } \\
\text { (percent) }\end{array}$ & $\begin{array}{c}\text { Indicted in } \mathbf{1 6 0 0} \\
\text { (percent) }\end{array}$ \\
\hline & 6.1 & 4.1 \\
Gentry/Professionals & 4.7 & 3.7 \\
Farmers & 31.5 & 28.6 \\
Laborers & 278 & 294 \\
Number in Sample & & \\
\hline
\end{tabular}

Source: UK, Census, 1851.

Table 17: Summary of the Results for the South East

\begin{tabular}{lcccc}
\hline Group & $\begin{array}{c}\text { N } \\
\text { South- } \\
\text { East }\end{array}$ & $\begin{array}{c}\text { Fraction of } \\
\text { names 1851 in } \\
\text { South East }\end{array}$ & $\begin{array}{c}\text { Median } \\
\text { Frequency } \\
1851\end{array}$ & $\begin{array}{c}\text { Name } \\
\text { disappeared } \\
\text { by 1851 } \\
\text { (percent) }\end{array}$ \\
& & & & 35 \\
Indicted & 337 & 0.46 & 9 & 21 \\
Poorest Testators & 147 & 0.62 & 36 & 19 \\
Middling Testators & 289 & 0.62 & 48 & 17 \\
Richest Testators & 204 & 0.67 & 67 & \\
& & & & \\
\hline
\end{tabular}

Source: UK, Census, 1851. 
Table 18: Summary of the Results for the rest of the Country

\begin{tabular}{lcccc}
\hline Group & $\begin{array}{c}\text { N } \\
\text { South- } \\
\text { East }\end{array}$ & $\begin{array}{c}\text { Fraction of } \\
\text { names 1851 } \\
\text { outside South } \\
\text { East }\end{array}$ & $\begin{array}{c}\text { Median } \\
\text { Frequency } \\
\mathbf{1 8 5 1}\end{array}$ & $\begin{array}{c}\text { Name } \\
\text { disappeared } \\
\text { by 1851 } \\
\text { (percent) }\end{array}$ \\
& & & & 33 \\
Indicted & 337 & 0.54 & 9 & 24 \\
Poorest Testators & 147 & 0.38 & 19 & 24 \\
Middling Testators & 289 & 0.38 & 22 & 20 \\
Richest Testators & 204 & 0.33 & 20 & \\
& & & & \\
\hline
\end{tabular}

Table 19: Exact versus inexact name matches 1851

\begin{tabular}{lcccc}
\hline \multicolumn{1}{c}{ Group } & Number & $\begin{array}{c}\text { Matches } \\
\text { under } \\
\text { original } \\
\text { name, 1851 }\end{array}$ & $\begin{array}{c}\text { Matches } \\
\text { under } \\
\text { variant } \\
\text { spellings }\end{array}$ & $\begin{array}{c}\text { Percent of } \\
\text { matches to the } \\
\text { original } \\
\text { spelling }\end{array}$ \\
& & & & 52 \\
Indicted & 278 & 18.4 & 35.7 & 54 \\
Poorest Testators & 159 & 28.6 & 52.8 & 50 \\
Middling Testators & 297 & 27.1 & 54.1 & 44 \\
Richest Testators & 206 & 28.3 & 64.5 & \\
& & & & \\
\hline
\end{tabular}

Source: UK, Census, 1851. 